\title{
ZNANJE SREDNJOŠKOLACA $O$ HOMOSEKSUALNOJ ORIJENTACIJI I SKLONOST DISKRIMINACIJI HOMOSEKSUALNIH OSOBA
}

\section{HIGH SCHOOL STUDENTS' KNOWLEDGE ABOUT HOMOSEXUAL ORIENTATION AND TENDENCY TO DISCRIMINATE AGAINST HOMOSEXUAL PERSONS}

\author{
Aleksandra Huić \\ Odsjek za psihologiju \\ Filozofski fakultet Sveučilišta u Zagrebu \\ Department of Psychology \\ Faculty of Humanities and Social Sciences, University of Zagreb \\ $\varangle$ E-mail:ahuic@ffzg.hr \\ Hana Greta Matković \\ Nanobit d. o. o. \\ Nanobit
}

\begin{abstract}
SAŽETAK
Cilj ovog istraživanja bio je ispitati odnos među znanjem srednjoškolaca o homoseksualnoj orijentaciji, percepciji zastupljenosti te teme u školi i sklonosti diskriminaciji homoseksualnih osoba. Dodatno nas je zanimalo hoće li postojeće znanje i stupanj sklonosti diskriminaciji igrati ulogu u tome koliko su učenici otvoreni pročitati dodatni edukacijski materijal o homoseksualnosti. Ispitivanje je provedeno online na uzorku od 312 srednjoškolaca. Koristili smo se Skalom znanja o homoseksualnoj orijentaciji i Skalom sklonosti diskriminaciji homoseksualnih osoba, te je s nekoliko pitanja ispitana percepcija zastupljenosti te teme u školi. Na kraju ispitivanja učenici su mogli odabrati žele li pročitati dodatni edukacijski materijal o tome. Pokazalo se da je znanje srednjoškolaca o homoseksualnoj orijentaciji nisko, te da su u vlastito znanje ili prilično nesigurni ili su, pak, presigurni u krive odgovore. Također, učenici izjavljuju da u sklopu obveznoga obrazovnog sustava nemaju često priliku čuti informacije o homoseksualnoj orijentaciji. Nije dobivena značajna povezanost između percepcije veće izloženosti temi i njihova znanja, međutim, učenici koji pohađaju etiku, imaju bolje znanje od učenika koji pohađaju vjeronauk. Povezanost između sklonosti diskriminaciji i njihova znanja pokazala se značajnom, odnosno manje su skloni diskriminirati oni srednjoškolci koji imaju bolje znanje o homoseksualnoj orijentaciji. Učenici s boljim znanjem i koji su manje skloni diskriminirati češće su odabirali pročitati dodatni edukacijski materijal o temi. Takvi rezultati mogli bi nas usmjeriti
\end{abstract}


prema tome što nedostaje obrazovnom sustavu u Hrvatskoj, na koji način možemo povećati znanje o homoseksualnoj orijentaciji te smanjiti sklonost diskriminaciji.

Ključne riječi: homoseksualna orijentacija, znanje o homoseksualnoj orijentaciji, sklonost diskriminaciji, obrazovne odrednice

\begin{abstract}
The goal of this study was to examine the relationship between high school students' knowledge about homosexual orientation, their perception of the presence of this topic in the curriculum and the tendency to discriminate against homosexual persons. In addition, we examined whether the levels of knowledge and discriminatory tendencies are related to students' readiness to read additional educational material on the topic. The study was conducted online and included 312 respondents. We used the Knowledge of Homosexual Orientation Scale, the Tendency to Discriminate Against Homosexual People Scale and a few questions about educational factors. At the end of the survey, the students could choose whether they wanted to read additional educational material on the topic. The findings show that high school students' knowledge about homosexual orientation is poor and that they are either very unsure of their own knowledge, or too sure of the wrong answers. Moreover, the students state that they do not often have the opportunity to hear about homosexual orientation within the curriculum. Their perception of these opportunities and their knowledge was not significantly related, although students who attend ethics classes had better knowledge than those who attend religious education. The correlation between knowledge and the tendency to discriminate proved significant, in that students with a higher level of knowledge about homosexual orientation were less likely to discriminate against homosexuals. Students with better knowledge about homosexuality and those less likely to discriminate chose to read additional educational material about homosexuality more commonly. These findings may help point us in the right direction as to what is missing in the Croatian education system, how we can improve knowledge about homosexuals and reduce the tendency to discriminate against them.
\end{abstract}

Key words: homosexual orientation, knowledge about homosexuality, tendency to discriminate, educational factors

\section{UVOD}

Unatoč sve većim zakonodavstvenim naporima (npr. Zakon o životnom partnerstvu), osobe homoseksualne orijentacije u hrvatskom društvu i dalje nisu ravnopravne osobama heteroseksualne orijentacije, te su često meta nasilja i diskriminacije. Na mapi Europskog udruženja za jednakost lezbijki, gejeva, biseksualnih, trans i interseksualnih osoba, Hrvatska postiže rezultat od tek $46 \%$ od 100 -postotne jednakosti i poštovanja ljudskih prava LGBT osoba (IlgaEurope, 2020). Hrvatska istraživanja provedena na homoseksualnim osobama pokazuju da je $60 \%$ - 70\% njih tijekom života bilo izloženo nekom obliku verbalnog i/ili fizičkog nasilja te diskriminacije u obliku odbijanja usluga (npr. prilikom usluživanja, iznajmljivanja stana i prilikom zapošljavanja) (Pikić i Jugović, 2006). Ti postotci nisu se promijenili u razdoblju od zadnjih desetak godina (vidi Kamenov, Jelić i Huić, 2016).

\section{INTRODUCTION}

Despite increasing legislative efforts (e.g. Civil Partnership Act), persons with homosexual orientation in Croatian society remain unequal to heterosexuals and are often the target of violence and discrimination. On a map by the European Association for the Equality of Lesbian, Gay, Bisexual, Trans and Intersex People, Croatia scores only $46 \%$ of the $100 \%$ equality and respect for the human rights of LGBT people (llga-Europe, 2020). Croatian research on homosexuals shows that $60-70 \%$ of them have been exposed to some form of verbal and/or physical violence and discrimination during their lifetime, in the form of a service denied (e.g. when being served, renting an apartment and during employment) (Pikić and Jugović, 2006). These percentages have not changed in the last ten years (see Kamenov, Jelić and Huić, 2016). 
Osim toga, stavovi opće populacije prema homoseksualnim pojedincima su negativni. Rezultati velikoga Eurobarometrova istraživanja (2019), provedenog na reprezentativnom uzorku, pokazuju da tek $44 \%$ Hrvata smatra da bi osobe homoseksualne orijentacije trebale imati ista prava kao i heteroseksualne osobe, a njih skoro $70 \%$ bi se osjećalo nelagodno ako bi vidjelo dva muškarca ili dvije žene da u javnosti pokazuju svoju uzajamnu simpatiju. Oko polovice građana (52\%) smatra da je diskriminacija osoba homoseksualne orijentacije iznimno rasprostranjena u Hrvatskoj.

Rijetka hrvatska istraživanja provedena na mlađoj populaciji pokazuju slične trendove. Studenti, čiji su stavovi u pravilu pozitivniji od stavova šire populacije, u istraživanjima pokazuju da ne bi podržali određena prava, primjerice usvajanje djece ili brak (Huić, Jugović i Kamenov, 2015). Visoki postotci hrvatskih maturanata (50\% - 60\%) također ne podržavaju usvajanje djece, osobama homoseksualne orijentacije ne bi dopustili rad s djecom, ne podržavaju javne istupe homoseksualnih osoba te smatraju da je homoseksualnost bolest (Bovan i Širinić, 2016). Iz tih se nalaza vidi da se negativni stavovi učenika temelje na neznanju o homoseksualnoj orijentaciji (npr. da se radi o bolesti), kao i da su učenici skloni aktivno diskriminirati osobe homoseksualne orijentacije (npr. zabranili bi im javno pokazivanje naklonjenosti).

Škola, kao odgojno-obrazovna institucija, predstavlja kontekst unutar kojeg bi mladi trebali dobiti valjane i pouzdane informacije o tome. Međutim, tema spolnosti i neheteroseksualnih orijentacija u školama se izbjegava. Zdravstveni odgoj, koji je trebao biti uveden u hrvatske škole još 2012. godine, obustavljen je zbog modula koji se bavio rodnom i spolnom ravnopravnošću. Prema izvještaju Ureda pravobraniteljice za ravnopravnost spolova o provođenju građanskoga i zdravstvenog odgoja
In addition, attitudes towards homosexual individuals in the general population are negative. The results of an extensive Eurobarometer survey (2019), conducted on a representative sample, show that only $44 \%$ of Croatians believe that homosexuals should enjoy the same rights as heterosexuals and almost $70 \%$ would feel uncomfortable to see two men or two women showing affection for each other in public. About half of the citizens (52\%) believe that discrimination against homosexuals is exceedingly widespread in Croatia.

Rare studies conducted on the younger population in Croatia show similar trends. Students, whose attitudes are generally more positive than those of the general population, show that they would not support certain rights, such as child adoption or marriage (Huić, Jugović and Kamenov, 2015). High percentages of Croatian high school graduates (50-60\%) do not support adopting children, would not allow homosexuals to work with children, do not support public expression of homosexuality, and consider homosexuality a disease (Bovan and Širinić, 2016). These findings show that students' negative attitudes are based on ignorance about homosexual orientation (e.g. considering it an illness), and that students tend to actively discriminate against homosexuals (e.g. by prohibiting them from showing affection in public).

The school, as an educational institution, constitutes a context within which young people should receive valid and reliable information about this topic. However, the topic of sexuality and non-heterosexual orientations is avoided in schools. Health education, which was supposed to be introduced in Croatian schools in 2012, was suspended because of a module dealing with gender and gender equality. According to a report by the Office of the Ombudswoman for Gender Equality on the 
u školama (2015), taj modul godinama nailazi na veliki otpor. Čini se da se stavovi prema tom pitanju još uvijek nisu promijenili s obzirom da oko $40 \%$ Hrvata smatra da u školski sustav ne bi trebalo uvoditi teme vezane uz homoseksualnu orijentaciju (Eurobarometar, 2019).

S obzirom na to da je adolescencija razvojno razdoblje u kojemu, na temelju informacija kojima smo izloženi, formiramo većinu svojih stavova prema društvenim pitanjima, a škola je iznimno važan razvojni kontekst u tom smislu, u ovom istraživanju zanimalo nas je: koliko zapravo srednjoškolci znaju o homoseksualnoj orijentaciji, na koji je način njihovo znanje povezano s onim što su čuli u školi o toj temi, te njihovo mišljenje o diskriminaciji homoseksualnih osoba. Dodatno, zanimalo nas je, hoće li ih stupanj znanja i izloženosti informacijama unutar obrazovnog sustava činiti otvorenijima za stjecanje znanja o homoseksualnoj orijentaciji. Postojeći hrvatski podatci o znanju i stavovima adolescenata o toj temi iznimno su rijetki, te ovo istraživanje predstavlja dodatni doprinos na tom polju.

\section{Znanstvene činjenice/mitovi o homoseksualnoj orijentaciji}

Prema Hereku (2000), homoseksualna orijentacija definira se kao višedimenzionalan konstrukt koji se sastoji od seksualne privlačnosti, ljubavnog odnosa, identiteta, ponašanja i članstva u zajednici. Ona se najčešće dijeli u tri kategorije, pri čemu se heteroseksualna orijentacija odnosi na privlačnost prema osobama suprotnog spola, homoseksualna orijentacija na privlačnost prema osobama istog spola, a biseksualnost na privlačnost prema osobama obaju spolova (Kelly, 2006). Danas se na seksualnu orijentaciju gleda kao na kontinuum na čijim su suprotnim točkama oni koje privlače isključivo osobe istog spola i oni koje privlače isključivo osobe suprotnog spola, dok se u implementation of civic and health education in schools (2015), this module was met with strong resistance over the years. It seems that attitudes towards this issue have not changed yet, given that about $40 \%$ of Croatians believe that topics related to homosexual orientation should not be introduced into the education system (Eurobarometer, 2019).

Considering that adolescence is a developmental period in which, based on the information we are exposed to, we form most of our attitudes towards social issues, the school being an extremely important developmental context in this regard, we were interested in this study in how much high school students really know about homosexual orientation, and in what ways their knowledge is related to what they heard about this topic in school, as well as to their tendency to discriminate. Additionally, we were interested in whether the level of knowledge and exposure to information within the education system would make them more open to acquiring knowledge about homosexual orientation. Existing Croatian data on adolescents' knowledge and attitudes about this topic are scarce, and this study represents an additional contribution in this field.

\section{Scientific Facts/Myths about Homosexual Orientation}

According to Herek (2000), homosexual orientation is defined as a multidimensional construct consisting of sexual attraction, love, identity, behavior, and community membership. It is most commonly divided into three categories, with heterosexual orientation referring to attraction to persons of the opposite sex, homosexual orientation to attraction to persons of the same sex, and bisexuality to attraction to persons of both sexes (Kelly, 2006). Today, sexual orientation is seen as a continuum whose opposite points are those attracted only by 
sredini nalaze oni koje podjednako privlače osobe obaju spolova. Neki se smještaju i između tih točaka, primjerice ako ih privlače uglavnom osobe suprotnog spola (Epstein, McKinney, Fox i Garcia, 2012; Savin-Williams, 2014). S obzirom na to da istraživanja pokazuju da se stavovi prema homoseksualnim osobama razlikuju od onih prema biseksualnim osobama, a i da se znanje o tim dvjema skupinama razlikuje i kod heteroseksualnih i kod homoseksualnih pojedinaca (Israel i Mohr, 2004), u ovom smo se istraživanju odlučili usmjeriti isključivo na znanje o homoseksualnoj orijentaciji. Pritom smo se usmjerili na činjenice koje obuhvaćaju opće znanje o homoseksualnim osobama, kao što je njihovo ponašanje u vezama, izvor homoseksualne orijentacije i slično.

Većina tih činjenica obuhvaća i česte mitove o homoseksualnim osobama koji mogu biti opasni, odnosno ispituje poznavanje istine umjesto stereotipa. Zbog toga smo se ciljano usmjerili na takve "mitove" o homoseksualnoj orijentaciji, a o kojima postoje znanstvene činjenice koje ih osporavaju. Posebno opasan mit tiče se uzroka homoseksualne orijentacije. Naime, istraživanja pokazuju da će pozitivnije stavove prema homoseksualnoj orijentaciji imati oni koji vjeruju da je ona urođena, odnosno da nije izbor (Haslam i Levy, 2006), što potvrđuju i hrvatska istraživanja (Huić, Jelić i Kamenov, 2018). Istraživanja pokazuju da je uzrok homoseksualnoj orijentaciji puno kompleksnije pitanje, odnosno da na nj ne postoji jednoznačan odgovor (APA, 2008). Homoseksualna orijentacija razvija se na temelju kompleksnih odnosa genetike, hormona te razvojnih, socijalnih i kulturnih čimbenika, a većina osoba kaže da nije imala izbor o vlastitoj seksualnoj orijentaciji. Ipak, česti mitovi su da je homoseksualnost bolest, izbor, da nastaje zbog zlostavljanja u djetinjstvu ili da je na neki drugi način uzrokuju roditelji. Ne postoje istraživanja koja pokazuju da će zlostavljana djeca people of the same sex and those attracted only by people of the opposite sex, with those equally attracted by people of both sexes in the middle. Some are also located between these points, for example if they are attracted mainly by people of the opposite sex (Epstein, McKinney, Fox, and Garcia, 2012; Savin-Williams, 2014). Given that research shows that attitudes toward homosexuals differ from those toward bisexuals and that understanding of these two groups differs in both heterosexual and homosexual individuals (Israel and Mohr, 2004), we decided to focus in this study solely on knowledge about homosexual orientation. In doing so, we focused on facts that include general knowledge about homosexual persons, such as their behavior in relationships, the source of homosexual orientation and the like.

Most of these facts involve frequent myths about homosexual persons that can be dangerous, that is, they question the knowledge of the truth instead of stereotypes. That is why we targeted such "myths" about homosexual orientation, which are challenged by scientific facts. One particularly dangerous myth concerns the causes of homosexual orientation. Namely, research shows that people who believe that homosexual orientation is innate, i.e. not a choice, tend to have more positive attitudes towards it (Haslam and Levy, 2006), which has been confirmed by Croatian research (Huić, Jelić and Kamenov, 2018). Research indicates that the cause of homosexual orientation is a much more complex question, as there is no unambiguous answer to it (APA, 2008). Homosexual orientation develops on the basis of complex relationships of genetics, hormones, and developmental, social and cultural factors, and most people say they had no choice about their own sexual orientation. Yet common myths persist that homosexuality is a disease, a choice, that it is caused by childhood abuse or otherwise brought about by parents. There 
u većem broju biti homoseksualne orijentacije (APA, 2008). Također, APA je još 1973. godine maknula dijagnozu homoseksualnosti kao bolesti iz DSM priručnika.

Daljnji je dokaz za to da se seksualna orijentacija ne može kontrolirati i činjenica da se ne može promijeniti, primjerice lijekovima ili terapijom. Tijekom povijesti bilo je različitih načina na koje se pokušavalo promijeniti seksualnu orijentaciju (reparativna ili konverzijska terapija). Istraživanja su pokazala da takve terapije nemaju nikakva učinka, te da mogu samo štetiti zbog toga što uzrokuju osjećaj krivnje i srama. Osim toga, te su terapije često bile i izrazito neugodne, bolne ili opasne, koristeći se metodama poput averzivne terapije, elektrokonvulzivne terapije (elektrošok), lobotomije, kemijske kastracije i sličnog (Haldeman, 2002).

Osim navedenoga, postoji i mit da su homoseksualne osobe češće bolesne ili sklone devijantnu ponašanju. lako su anksioznost i depresija češći unutar LGBT populacije, kao i zloporaba droga i alkohola, pokazuje se da je uzrok tomu stres koji uzrokuje marginalizacija i stigmatizacija te manjine (Meyer, 2003). Vanjski stresori i nedostatak socijalne podrške ono je što utječe na razlike u zdravlju među seksualnim orijentacijama. Također, HIV se često povezuje s homoseksualnom orijentacijom, pa tako i u hrvatskim udžbenicima, dok je to u stvarnosti virus kojim se svi mogu zaraziti. Zaraza je češća unutar muške homoseksualne i biseksualne populacije, no, među ostalim, i zbog stigmatizacije zbog koje se homoseksualni i biseksualni muškarci rjeđe testiraju i dijagnosticiraju na vrijeme (HIV and Gay and Bisexual Men Understanding HIV/AIDS, 2018). Osim toga, ako se uzmu u obzir metodološki nedostatci tih istraživanja (npr. razlike u uzorkovanju između heteroseksualne i homoseksualne orijentacije) zapravo ne možemo biti sigurni jesu li infekcije are no studies proving that abused children tend to be homosexual in greater numbers (APA, 2008). Furthermore, the APA removed the diagnosis of homosexuality as a disease from the DSM manual back in 1973.

Further evidence that sexual orientation cannot be controlled is the fact that it cannot be changed, for example by medication or therapy. Throughout history, there have been various ways in which attempts have been made to change sexual orientation (through reparative or conversion therapy). Research has shown that such therapies have no effect, and can only do harm because they give rise to the feelings of guilt and shame. Additionally, such therapies have often been acutely uncomfortable, painful, or dangerous, using methods such as aversion therapy, electroshock therapy, lobotomy, chemical castration and the like (Haldeman, 2002).

In addition to the above, there is a myth that homosexuals are more often ill or prone to deviant behavior. Although anxiety and depression are more common within the LGBT population, as well as drug and alcohol abuse, this appears to be caused by stress brought about by the marginalization and stigmatization of this minority (Meyer, 2003). It is external stressors and lack of social support that affects health differences between sexual orientations. HIV is also often associated with homosexual orientation, including in Croatian school textbooks, while in reality it is a virus that can infect everyone. Infection is more common within the male homosexual and bisexual population, but also due to stigma, which makes homosexual and bisexual men less likely to be tested and diagnosed on time (HIV and Gay and Bisexual Men Understanding HIV/AIDS, 2018). In addition, given the methodological shortcomings of these studies (e.g. differences in sampling between heterosexuals and homosexuals) we 
Aleksandra Huić, Hana Greta Matković: Znanje srednjoškolaca o homoseksualnoj orijentaciji i sklonost...

HIV-om zaista češće unutar homoseksualne populacije u cjelini (Meyer, 2003).

Još jedan čest i negativan mit je da homoseksualne osobe češće zlostavljaju djecu od heteroseksualnih, no istraživanja pokazuju upravo suprotno (APA, 2008) Također, čest mit je i da istospolni parovi na neki način štete svojoj djeci, što je i jedan od razloga zbog kojih im je teško ostvariti pravo na posvajanje djece. Istraživanja pokazuju da se homoseksualni roditelji ne razlikuju od heteroseksualnih roditelja, odnosno da djeci mogu pružiti barem jednako dobar odgoj, odrastanje i razvoj (American Academy of Child \& Adolescent Psychiatry, AACAP, 2013). I Američka udruga psihologa (APA) i Američka akademija pedijatara (AAP) nekoliko su puta opovrgnule taj mit te podržale kampanju da se istospolnim osobama omogući posvajanje djece (APA, 2008).

\section{Tema homoseksualnosti u hrvatskom obrazovnom sustavu}

Prema izvještaju udruge GALE (Global Alliance for LGBT Education), u kojem je analizirana zastupljenost LGBT tematike u kurikulima svih europskih država, Hrvatska se našla na sredini ljestvice te je ocijenjena kao "ambiguous", odnosno nesigurna ili dvoznačna. U izvještaju napominju da je obrazovanje o spolnosti ispod standarda, a da ga ondje zadržava utjecaj Katoličke Crkve (Dankmeijer, 2017; str. 71). Dublji pogled daje nam analiza LGBT tematike u udžbenicima za osnovnu i srednju školu (Brumen, 2012) u kojoj je detaljno prikazano u kojim razredima i na kojim se predmetima učenici imaju prilike susresti s LGBT tematikom u sklopu nastave. Gowen i Winges-Yanez (2014) postavili su model isključivoga spolnog odgoja, a prema tom modelu isključivi je spolni odgoj onaj koji je heteronormativan ${ }^{1}$ i neprilagođen

\footnotetext{
1 Heteronormativnost se definira kao pretpostavka da su svi heteroseksualni, odnosno da je heteroseksualnost idealna superiorna u odnosu na homoseksualnost ili biseksualnost. Također, uključuje i privilegiranje normativnog izražavanja roda (Spahić i Gavrić, 2012).
}

cannot claim with certainty whether HIV infections are indeed more common within the homosexual population as a whole (Meyer, 2003).

Another common negative myth is that homosexuals abuse children more often than heterosexuals, although research shows just the opposite (APA, 2008). It is also a common myth that same-sex couples harm their children in some way, which is one of the reasons why they find it difficult to exercise the right to adopt children. Research shows that homosexual parents are no different from heterosexual parents, i.e. they can provide children with at least equally good upbringing, growth and development (American Academy of Child \& Adolescent Psychiatry, AACAP, 2013). Both the American Psychological Association (APA) and the American Academy of Pediatrics (AAP) have repeatedly refuted this myth, and supported a campaign to allow same-sex individuals to adopt children (APA, 2008).

\section{Topic of Homosexuality in the Croatian Education System}

According to a report by the GALE association (Global Alliance for LGBT Education) which analyzes the presence of LGBT issues in the curricula of all European countries, Croatia is in the middle of the scale and is rated as "ambiguous", or uncertain. The report notes that sex education is below standard, maintained there by the influence of the Catholic Church (Dankmeijer, 2017; p. 71). A deeper insight is provided by an analysis of LGBT topics in elementary and high school textbooks (Brumen, 2012), which demonstrates in detail the grades and subjects in which students have the opportunity to encounter LGBT issues in the classroom. Gowen and Winges-Yanez (2014) identified the model of exclusive sex education, according to which exclusive sex 
LGBT pojedincima i učenju o LGBT tematici, a obuhvaća tri načina isključivanja - prešućivanje, koje može biti aktivno i pasivno, heterocentrizam i patologiziranje. Pasivno prešućivanje odnosi se na nespominjanje LGBT tematike $u$ obrazovnom programu, a aktivno podrazumijeva skretanje s te teme ili odbijanje davanja odgovora. Heterocentrizam se odnosi na pristup spolnom odgoju iz isključivo heteroseksualne perspektive. Patologiziranje označava pristup seksualnoj orijentaciji u kojem se ona uparuje s patološkim, primjerice spolnim bolestima i mentalnim poremećajima.

Kombinacija prešućivanja i heterocentrizma prisutna je u većini udžbenika za srednje škole. U udžbenicima iz biologije tijekom cijelog obrazovanja spolni je odnos prikazan iz heteroseksualne perspektive, a čak se i promjene u pubertetu komentiraju heteronormativno „pojavljuje se interes za suprotni spol”, „mladića zanima sve o ženskom spolu“, „tijekom puberteta osobito je izražena mašta i snovi u kojima se često javlja želja za spolnim sjedinjenjem s osobom suprotnog spola" (Brumen, 2012; str. 32). Spolni odnos opisan je isključivo kao „penetracija uda u vaginalni kanal” (Brumen, 2012; str. 33). U udžbenicima za strukovne škole, tijekom svih godina obrazovanja, LGBT kao pojam spomenut je samo u udžbeniku iz Politike i gospodarstva, a spolnost se spominje samo na biologiji, i to heterocentrično. $U$ udžbenicima za gimnazije, LGBT tematika najdetaljnije je obrađena na etici, počevši od objašnjenja pojmova kao što su LGBT i queer, do definicija spolne orijentacije i toga kako se ona najčešće kategorizira (homoseksualna, heteroseksualna, biseksualna). Zatim se ta tematika spominje na sociologiji i filozofiji. Važno je napomenuti da su politika i gospodarstvo, sociologija i filozofija u većini škola jednogodišnji predmeti, te da je opseg znanja dobiven na tim predmetima samim time smanjen. education is one that is heteronormative ${ }^{1}$ and unadapted to LGBT individuals and learning about LGBT issues, and includes three ways of exclusion - silence, which can be active and passive, heterocentrism and pathologizing. Passive silence refers to not mentioning LGBT issues in the curriculum, while active silence implies departing from that topic or refusing to provide answers. Heterocentrism refers to approaching sex education from a purely heterosexual perspective. Pathologization refers to approaching sexual orientation by pairing it with the pathological, such as sexually transmitted diseases and mental disorders.

A combination of silence and heterocentrism is present in most high school textbooks. In biology textbooks, sexual intercourse is presented from a heterosexual perspective throughout education, and even changes in puberty are described heteronormatively "interest in the opposite sex appears", "young men become interested in everything about women", "during puberty, imagination is particularly pronounced, including dreams in which there is often a desire for sexual union with a person of the opposite sex" (Brumen, 2012; p. 32). Sexual intercourse is described exclusively as "penetration of the penis into the vagina" (Brumen, 2012; p. 33). In vocational school textbooks, through all grades, the term LGBT is mentioned only in a textbook on politics and economics, while sexuality is mentioned only in biology, and heterocentrically. In grammar school textbooks, LGBT topics are dealt with in the most detail in the subject of ethics, from explaining concepts such as LGBT and queer, to defining sexual orientation and how it is most commonly categorized (homosexual, heterosexual, bisexual). This topic is also mentioned in sociology and philosophy. It is important to

\footnotetext{
1 Heteronormativity is defined as the assumption that everyone is heterosexual, that is, that heterosexuality is ideal and superior to homosexuality or bisexuality. It also includes the privilege of normative gender expression (Spahić and Gavrić, 2012).
} 
Pristup patologiziranja prisutan je u udžbenicima iz biologije i vjeronauka za srednje škole. U udžbeniku iz biologije homoseksualna orijentacija povezuje se s HIV-om, odnosno homoseksualnost je prikazana u kontekstu bolesti (Brumen, 2012). Na vjeronauku se spolnost spominje tek u 3. razredu, gdje se navodi da su oni u homoseksualnim odnosima "lišeni svoga bitnog i nenadomjestivog cilja" te da "trpe nastranost" (Brumen, 2012; str. 24). U udžbeniku iz filozofije homoseksualnost je spomenuta i u tezi za razmišljanje i raspravu koja glasi "Homoseksualni brakovi su neprihvatljivi zato što su neprirodni" (Brumen, 2012; str. 37). Može li se na to gledati kao na patologiziranje, možda je diskutabilno, no postavlja se pitanje, nije li ta teza mogla biti postavljena i u pozitivnom tonu.

\section{Znanje i sklonost diskriminaciji homoseksualnih osoba}

U ovom istraživanju specifično nas je zanimala sklonost diskriminaciji, odnosno sklonost negativnu ponašanju prema homoseksualnim osobama. Dosadašnja istraživanja minimalno su se usmjerila na taj aspekt, uglavnom ispitujući samo sklonost adolescenata da dopuste/ zabrane istospolni brak i posvajanje djece. Osim toga, iako postoje istraživanja koja pokazuju da je veće znanje o homoseksualnoj orijentaciji povezano s manje homonegativnim stavovima (Alderson, Orczek i McEwan, 2009; Hubbard i sur., 2013), nedostaje istraživanja koja izravnije povezuju znanje i sklonost diskriminaciji.

Na temelju istraživanja koja evaluiraju intervencijske programe i treninge, čiji je cilj smanjiti sklonost diskriminaciji ili poboljšati stavove prema homoseksualnoj orijentaciji, znamo da bolje znanje o homoseksualnoj orijentaciji smanjuje predrasude (Cramwinckel, Scheepers i van der Toorn, 2018; Hubbard i sur., 2013), međutim, ne dovodi nužno do manje sklonosti diskriminaciji. Primjerice, $\mathrm{u}$ note that politics and economics, sociology, and philosophy are one-year subjects in most schools and that the amount of knowledge acquired in these subjects is thus limited.

The pathologizing approach is present in biology and religious education textbooks for high schools. In a biology textbook, homosexual orientation is associated with the HIV virus, i.e. homosexuality is presented in the context of disease (Brumen, 2012). In religious education, sexuality is only mentioned in the third grade, where it is claimed that persons in homosexual relationships are "deprived of their essential and irreplaceable goal" and that they "suffer queerness" (Brumen, 2012; p. 24). Homosexuality is also mentioned in a philosophy textbook, in a topic for reflection and discussion which reads "Homosexual marriages are unacceptable because they are unnatural" (Brumen, 2012; p. 37). Whether this can be seen as pathologizing may be debatable, but the question arises as to whether this topic may have been formulated in a positive tone.

\section{Knowledge and Tendency to Discriminate Against Homosexuals}

We were specifically interested in this study in the tendency to discriminate, i.e. tendency for negative behavior towards homosexuals. Previous research has focused very little on this aspect, mainly examining only the tendency of adolescents to allow/ban same-sex marriage and child adoption. Besides, although there is research showing that greater knowledge about homosexual orientation is associated with less homonegative attitudes (Alderson, Orczek, and McEwan, 2009; Hubbard et al., 2013), there is a lack of research that more directly links knowledge and tendency to discriminate.

Based on research evaluating intervention programs and training aimed at reducing discrimination or improving attitudes toward 
jednom se istraživanju pokazalo da je gledanje informativnih videa o biološkim čimbenicima koji utječu na formiranje seksualne orijentacije čak povećalo predrasude (Deese i Dawson, 2013). U drugome, pak, poučavanje o biološkoj determiniranosti i nepromjenjivosti seksualne orijentacije uopće nije dovelo do smanjivanja seksualnih predrasuda, iako poučavanje o seksualnoj orijentaciji kao višedimenzionalnom konstruktu i kontinuumu jest (Hegarty, 2010).

Osim toga, postoje dokazi da uključivanje teme u formalno obrazovanje može pomoći boljem znanju o homoseksualnoj orijentaciji. Ispitujući ulogu kolegija Psihologija homoseksualnosti u oblikovanju stavova heteroseksualnih studenata Waterman, Reida, Garfield i Hoy (2001) pronašli su da su na kraju kolegija studenti iskazivali značajno niži stupanj homofobije u odnosu na početak kolegija. Porter i Krinsky (2014) proveli su istraživanje na skrbnicima starijih osoba, kojima su ponudili edukaciju o starenju LGBT pojedinaca. Na kraju istraživanja ne samo da su statistički značajno poboljšali znanje, stavove i namjere ponašanja nego su se skrbnici osjećali sigurnijima u svoje sposobnosti rada s LGBT osobama. Metaanaliza efekata intervencija na smanjivanje seksualnih predrasuda pokazala je da edukacijske intervencije u velikoj mjeri utječu na povećanje znanja o homoseksualnoj orijentaciji, dok su efekti na stavove srednje veličine (Bartos, Berger i Hegarty, 2014).

Općenito, istraživanja pokazuju da su promjene stavova, vjerovanja i vrijednosti do kojih dolazi zbog povećanja znanja uglavnom dugotrajne i stabilne (Ohlander, Batalova i Treas, 2005), te ne čudi značajan efekt tog znanja na stavove prema homoseksualnoj orijentaciji. Međutim, koliki je učinak tog znanja na namjeru ponašanja, odnosno sklonost diskriminaciji homoseksualnih osoba još uvijek je otvoreno pitanje (vidi i Bartos, Berger i Hegarty, 2014). S homosexual orientation, we know that better knowledge about homosexual orientation reduces prejudice (Cramwinckel, Scheepers, and van der Toorn, 2018; Hubbard et al., 2013), while not necessarily leading to less discrimination. For example, one study found that watching informative videos on biological factors influencing the formation of sexual orientation even increased prejudice (Deese and Dawson, 2013), while in another teaching about biological determinism and immutability of sexual orientation did not lead to a reduction in sexual prejudice, although teaching about sexual orientation as a multidimensional construct and continuum did (Hegarty, 2010).

In addition, there is evidence that including this topic in formal education can help improve knowledge about homosexual orientation. Examining the role of the course Psychology of Homosexuality in shaping the attitudes of heterosexual students, Waterman, Reida, Garfield, and Hoy (2001) found that, at the end of the course, students exhibited a significantly lower degree of homophobia compared to the beginning of the course. Porter and Krinsky (2014) conducted a study of caregivers of the elderly, who were offered training on the aging of LGBT individuals. By the end of the study, not only did the caregivers' knowledge, attitudes, and behavioral intentions statistically significantly improve, but they also felt more confident in their ability to work with LGBT people. Meta-analysis of the effects of interventions on reducing sexual prejudice has shown that educational interventions greatly affect the increase in knowledge about homosexual orientation, while the effects on attitudes remain moderate (Bartos, Berger, and Hegarty, 2014).

Generally, research shows that changes in attitudes, beliefs, and values due to increased knowledge are mostly long-lasting and stable (Ohlander, Batalova, and Treas, 2005), so it is 
Aleksandra Huić, Hana Greta Matković: Znanje srednjoškolaca o homoseksualnoj orijentaciji i sklonost...

obzirom na to da je namjera ponašanja najjači prediktor stvarnog ponašanja (Ajzen, 1991), smatramo da je upravo odnos znanja i sklonosti diskriminaciji važno pobliže ispitati. Dodatno, cjeloživotni stavovi formiraju se tijekom adolescencije, što populaciju srednjoškolaca čini posebno važnom za produbljivanje spoznaja o tom odnosu.

\section{Otvorenost za novo znanje}

Kognitivni pristup pretpostavlja da je ljudsko znanje o nekoj temi organizirano u obliku mentalnih reprezentacija u mozgu, a koje se često nazivaju shemama. Sheme usmjeravaju našu pažnju prema relevantnim informacijama, te nam daju okvir za procjenu tih informacija (Markus i Zajonc, 1985). Brojna istraživanja iz područja socijalne kognicije pokazuju da smo, u situacijama kada smo izloženi nekim novim informacijama, uglavnom motivirani usmjeriti pozornost prema onim informacijama koje su u skladu s našim postojećim znanjem o nekoj temi, što je povezano i s tim da ćemo nekad biti motivirani ne izlagati se novim informacijama koje bi mogle dovesti u pitanje naše postojeće znanje i uvjerenja (vidi Fiske i Taylor, 2013 za pregled). U kontekstu obrazovanja takav način funkcioniranja ljudskog mozga može biti posebno problematičan. S druge strane, neka istraživanja iz psihologije obrazovanja pokazuju da već izloženost informacijama o nečemu može povećati motivaciju za daljnjim učenjem o tome (Ditta i sur., 2020), posebno ako je znanje novo, iznenađujuće te ga učenici percipiraju korisnim (Fletcher i sur., 2001; Harackiewicz i sur., 2012). Zbog toga nas je dodatno zanimalo, hoće li učenici odabrati proširenje svojeg znanja o znanstvenim činjenicama vezanima uz homoseksualnu orijentaciju i odlučiti se na čitanje dodatnih materijala o homoseksualnoj orijentaciji, te na koji način njihov izbor ovisi o njihovu postojećem znanju o tome i o njihovoj sklonosti diskriminaciji. Te su spoznaje not surprising that such knowledge has a significant effect on attitudes toward homosexual orientation. However, the extent to which this knowledge has an effect on, or tendency to discriminate against homosexuals, remains an open question (see also Bartos, Berger, and Hegarty, 2014). Given that behavioral intention is the strongest predictor of actual behavior (Ajzen, 1991), we believe that it is the relationship between knowledge and tendency to discriminate that needs to be examined more closely. Additionally, lifelong attitudes are formed during adolescence, making the high school population particularly important for deepening knowledge about this relationship.

\section{Openness to New Knowledge}

The cognitive approach assumes that human knowledge of a topic is organized in the form of mental representations in the brain, often referred to as schemas. Schemes focus our attention on relevant information, and give us a framework for evaluating that information (Markus and Zajonc, 1985). Numerous studies in the field of social cognition indicate that, in situations when we are exposed to some new information, we are mostly motivated to pay attention to information that is consistent with our existing knowledge on a topic, which is related to the fact that, on occasions, we are motivated not to be introduced to new information that could bring our existing knowledge and beliefs into question (see Fiske and Taylor, 2013 for a review). In the context of education, this way of human brain functioning can be particularly problematic. On the other hand, some research in educational psychology shows that exposure to information on a particular topic can increase motivation for further learning on the topic (Ditta et al., 2020), especially if the knowledge is new, surprising and students perceive it as useful (Fletcher et 
potencijalno praktično važne onima koji će u sklopu obrazovnog sustava poučavati o tome.

\section{Cilj i svrha rada}

Cilj ovog istraživanja bio je ispitati odnos među znanjem srednjoškolaca o homoseksualnoj orijentaciji, obrazovnih odrednica koje imaju ulogu u tom znanju i sklonosti diskriminaciji homoseksualnih osoba. U skladu s ciljem, istraživanje se bavilo sljedećim problemima:

1. Ispitati kakvo je znanje srednjoškolaca o homoseksualnoj orijentaciji.

2. Ispitati ulogu percepcije zastupljenosti sadržaja o homoseksualnim osobama u srednjoškolskom obrazovanju i znanju srednjoškolaca o homoseksualnoj orijentaciji.

Hipoteza 2.1.: Pretpostavili smo da će učenici, koji izjavljuju da su na više školskih predmeta slušali o homoseksualnoj orijentaciji te iskazuju da su u većoj mjeri bili izloženi toj temi u sklopu obrazovnog programa, imati i bolje znanje.

Hipoteza 2.2.: Pretpostavili smo da će učenici koji pohađaju nastavu etike imati bolje znanje o homoseksualnoj orijentaciji od učenika koji pohađaju nastavu vjeronauka.

3. Ispitati povezanost između znanja srednjoškolaca o homoseksualnoj orijentaciji i njihovoj sklonosti diskriminiranju homoseksualnih osoba.

Hipoteza: Pretpostavili smo da će učenici s boljim znanjem o homoseksualnoj orijentaciji biti manje skloni diskriminaciji.

4. Ispitati razlikuju li se učenici koji odabiru pročitati dodatni materijal o homoseksualnoj orijentaciji (i time proširiti svoje znanje) u svojem znanju o temi, te sklonosti diskriminaciji osoba al., 2001; Harackiewicz et al., 2012). Therefore, we were additionally interested in whether the students would choose to expand their knowledge of scientific facts related to homosexual orientation and decide to read additional material on homosexual orientation, and how their choice depends on their existing knowledge of the topic and their tendency to discriminate. These insights are potentially practically important to those who will be teaching about this topic within the education system.

\section{Aim and Objectives}

The aim of this study was to examine the relationship between high school students' knowledge about homosexual orientation, educational determinants that play a role in that knowledge, and the tendency to discriminate against homosexuals. In line with this aim, the study addressed the following problems:

1. Examine the knowledge of high school students about homosexual orientation. Examine the role of the perception of presence of content about homosexual persons in secondary education in the knowledge of high school students about homosexual orientation.

Assumption 2.1: We assumed that students who state that they have heard about homosexual orientation in several school subjects and have been more exposed to this topic within the curriculum would also have better knowledge.

Assumption 2.2: We assumed that students attending ethics classes would have better knowledge about homosexual orientation than students attending religious education classes.

2. Examine the relationship between high school students' knowledge about homosexual orientation and their tenden- 
homoseksualne orijentacije od učenika koji ne odabiru dodatni materijal.

Hipoteza: S obzirom da se u ovom istraživanju ispituje znanje o jednoj društvenoj skupini, a ne o klasičnim školskim predmetima, svoju hipotezu temeljimo na spoznajama iz socijalne kognicije pa smo pretpostavili da će oni s manje znanja, i oni skloniji diskriminaciji, u manjoj mjeri odabrati čitanje informacija o homoseksualnoj orijentaciji jer bi takva odluka bila u većoj mjeri u skladu s njihovim shemama.

\section{METODOLOGIJA}

\section{Sudionici}

U istraživanju je sudjelovalo 312 učenika srednjih škola, od čega $75 \%$ učenica i $25 \%$ učenika. Sudjelovali su učenici gimnazija (76,6\%), strukovnih škola (16,3\%), umjetničkih škola $(2,6 \%)$ te učenici koji paralelno pohađaju dvije vrste srednjih škola (4,5\%). Gotovo pola sudionika $(47,4 \%)$ pohađa drugi razred srednje škole, $8 \%$ prvi, 16,3\% treći, a 27,3 \% četvrti. Samo je dvoje sudionika pohađalo peti razred petogodišnje strukovne škole. Dob sudionika kreće se u rasponu od 14 do 20 godina, pri čemu je prosjek $M=16,79$, a raspršenje $S D=1,03$. Većina učenika izjasnila se kao heteroseksualna (86\%), njih 10\% izjasnilo se biseksualnim, dok je $4 \%$ homoseksualnih učenika.

\section{Instrumenti}

Znanje o homoseksualnoj orijentaciji ispitali smo skalom konstruiranom za potrebe ovog istraživanja. Pitanja su se temeljila na različitim mitovima / znanstvenim činjenicama o homoseksualnoj orijentaciji te na Skali informiranosti o homoseksualnoj orijentaciji cy to discriminate against homosexuals. Assumption: We assumed that students with better knowledge about homosexual orientation would be less prone to discrimination.

3. Examine whether students who choose to read additional material on homosexual orientation (and thus expand their knowledge of the topic) differ in their knowledge of the topic, as well as their tendency to discriminate against homosexuals, from students who do not choose additional material.

Assumption: As this study examines knowledge about a social group, and not about school subjects, we based our assumption on notions from social cognition, assuming that those with less knowledge, and those more prone to discrimination, would choose to read less information on homosexual orientation, as such decision would be more in line with their schemas.

\section{METHOD}

\section{Participants}

All in all, 312 high school students participated in the study, of which $75 \%$ were female and $25 \%$ were male. Students from grammar schools (76.6\%), vocational schools (16.3\%), art schools (2.6\%) and students attending two types of secondary school in parallel (4.5\%) participated. Almost half of the respondents (47.4\%) attend the second grade of high school, $8 \%$ the first, $16.3 \%$ the third, and $27.3 \%$ the fourth. Only two respondents attend the fifth grade of a five-year vocational school. The respondents' age ranged from 14 to 20 years, with the mean $M=16.79$ and the dispersion $S D=1.03$. The 
(Wells i Franken, 1987) korištenoj u istraživanju Aldersona, Orzeck i McEwena (2009). Skala sadrži 19 tvrdnji o homoseksualnoj orijentaciji i osobama homoseksualne orijentacije. Zadatak sudionika je za svaku tvrdnju odgovoriti smatra li da je točna $(T)$, netočna $(N)$ ili ne znam (vidi tablicu 1 u rezultatima). Ukupan rezultat na skali predstavlja zbroj točnih odgovora, pri čemu je moguć raspon rezultata od 0 do 19. Pouzdanost tipa unutarnje konzistencije je zadovoljavajuća $(\alpha=0,80)$.

Percepciju zastupljenosti obrazovnih sadržaja na temu homoseksualne orijentacije u školi ispitali smo s nekoliko pitanja. Učenici su odgovorili na pitanje: „Jeste li u sklopu redovne nastave u školi slušali o temi homoseksualnosti?" na skali 1 - 5 koja se kretala od percepcije nulte izloženosti temi do višeg stupnja izloženosti (za detalje vidi tablicu 2 u rezultatima). Da bismo provjerili jesu li o temi homoseksualnosti čuli na više školskih predmeta, učenike smo pitali na kojim su predmetima imali prilike slušati o tome, pri čemu su, među ponuđenim predmetima, trebali označiti sve predmete na kojima su spominjali temu (uz ostavljenu mogućnost dodavanja predmeta koji nisu bili ponuđeni). S obzirom na različit pristup temi homoseksualne orijentacije na nastavi etike i nastavi vjeronauka, a i međusobnu isključivost tih dvaju predmeta, dodatno smo prikupili informaciju pohađaju li učenici etiku ili vjeronauk.

Skala sklonosti diskriminaciji preuzeta je iz istraživanja Huić, Jelić i Kamenov (2016) u kojem su sudjelovali odrasli pripadnici opće populacije, te je prilagođena za potrebe ovog istraživanja. Preuzete su one čestice koje se mogu odnositi na srednjoškolsku populaciju, a u pojedinim česticama vokabular je prilagođen srednjoj školi. Na ukupno 12 čestica, koje opisuju različita ponašanja u situacijama koja uključuju homoseksualne pojedince, učenici su odgovarali DA (ako smatraju da bi se i sami majority of students declared themselves as heterosexual (86\%), 10\% declared themselves as bisexual, and $4 \%$ declared themselves as homosexual.

\section{Instruments}

We examined knowledge about homosexual orientation using a scale constructed for the purposes of this study. The questions were based on various myths/scientific facts about homosexual orientation and the Knowledge of Homosexual Orientation Scale (Wells and Franken, 1987) used in research by Alderson, Orzeck, and McEwen (2009). The scale contains 19 statements about homosexual orientation and homosexuals. The respondents are asked to reply whether they think each statement is true $(\mathrm{T})$, false $(\mathrm{F})$ or they do not know (see Table 1 in the Findings). The total score on the scale represents the sum of the correct answers, with a possible range of results from 0 to 19 . The reliability of the internal consistency type is acceptable $(\alpha=0.80)$.

We examined the perception of the presence of educational content on the topic of homosexual orientation in school with several questions. The students answered the question "Did you hear about homosexuality as part of regular school classes?" on a scale of 1-5, which ranged from the perception of zero exposure to the topic to a higher level of exposure (for details see Table 2 in the Findings). To check if they had heard about the topic of homosexuality in more than one school subject, we asked the students in which subjects they had had the opportunity to hear about the topic, where, among the offered subjects, they were asked to mark all subjects where the topic had been mentioned (with a possibility to add subjects that were not offered). Given the different approaches to the topic of homosexual orientation in ethics and religious education, and the mutual exclusivity 
ponašali na način opisan u tvrdnji) ili NE (ako smatraju da se ne bi ponašali na takav način). Svih 12 čestica opisuje ponašanja kojima se na neki način diskriminira homoseksualna osoba samo zbog svoje seksualne orijentacije (vidi tablicu 5 u rezultatima), tako da odgovori DA ujedno označavaju sklonost diskriminaciji homoseksualnih osoba. Ukupni rezultat zbroj je čestica na koje je sudionik odgovorio potvrdno (TR $=0-12)$, a viši rezultat upozorava na veću sklonost diskriminaciji. Pouzdanost tipa unutarnje konzistencije je visoka $(\alpha=0,84)$.

\section{Postupak}

Podatci su prikupljeni online u proljeće 2018. godine. Sudionici su rješavali upitnik putem poveznice koja je objavljena na različitim društvenim mrežama. Na početku upitnika sudionicima je prezentirana opća uputa, uz napomenu da moraju potvrditi da imaju više od 14 godina i da su informirali roditelje, te je objašnjeno da je anonimnost zajamčena i da mogu odustati od ispitivanja u svakom trenutku. Ispunjavanje upitnika trajalo je oko 20 minuta. Istraživanje je dobilo potvrdu Etičkog povjerenstva Odsjeka za psihologiju Filozofskog fakulteta Sveučilišta u Zagrebu. Sudionicima je dan kontakt na koji se mogu javiti s pitanjima i s komentarima, a na kraju upitnika mogli su odabrati i pročitati edukacijski materijal o homoseksualnoj orijentaciji.

\section{REZULTATI}

U sklopu prvoga istraživačkog problema zanimalo nas je kakvo je znanje srednjoškolaca o homoseksualnoj orijentaciji. U tablici 1 prikazana je čestina biranja ispravnih i neispravnih odgovora, te odgovora "ne znam". Najveću nesigurnost učenici su pokazali na tvrdnjama Heteroseksualni profesori spolno zlostavljaju svoje učenike ili studente češće od homoseksualnih of these two subjects, we additionally collected information on whether the students attended ethics or religious education.

The scale of tendency to discriminate was taken from the research by Huić, Jelić and Kamenov (2016) in which adult members of the general population participated, and which was adjusted for the purposes of this study. Items that can refer to the high school population were used, and in some items the vocabulary was adjusted to the high school population. The students were given a total of 12 items describing different behaviors in situations involving homosexual individuals, and answered YES (if they thought they would behave as described) or NO (if they thought they would not behave in such a way). All 12 items describe behaviors that discriminate against homosexual persons in some way because of their sexual orientation alone (see Table 5 in the Findings), so that the answers YES indicate a tendency to discriminate against homosexual persons. The total score is the sum of the items to which the respondent answered affirmatively ( $T R=0-12$ ), and a higher score indicates a greater tendency to discriminate. The reliability of the internal consistency type is high ( $\alpha=0.84)$.

\section{Procedure}

Data were collected online in the spring of 2018. The respondents answered the questionnaire through a link posted on various social networks. At the beginning of the questionnaire, the respondents were presented with general instructions, noting that they must confirm that they were over 14 years old and they had informed their parents, and were explained that anonymity was guaranteed and that they could quit the survey at any time. Completing the questionnaire took about 20 minutes. The study was approved by the Ethics Committee of the Department of Psychology, 
profesora (50,3\% odgovorilo je "Ne znam") i Povijesno gledano, značajan broj homoseksualaca napravio je neki veliki doprinos društvu (51,3\% odgovorilo je "Ne znam"). Najveću sigurnost (samo 8,7\% odgovora "Ne znam") učenici su pokazali za tvrdnju Homoseksualce je lako prepoznati prema izgledu, stilu ili načinu izražavanja. Međutim, važno je istaknuti da je većina njih sigurna u potpuno krivi odgovor (samo 41,7\% njih ispravno je odgovorilo da je tvrdnja netočna).

Najveći postotak točnih odgovora dobila je tvrdnja Homoseksualni muškarci mrze žene $i$ homoseksualne žene mrze muškarce $(85,6 \%$ sudionika odgovorilo je ispravno da ta tvrdnja nije točna), a najmanji postotak točnih odgovora Heteroseksualni profesori spolno zlostavljaju svoje učenike ili studente češće od homoseksualnih profesora ( $24,7 \%$ sudionika odgovorilo je ispravno da ta tvrdnja nije točna). Najveći postotak krivog odgovora donosi tvrdnja $U$ posljednjih 25 godina homoseksualnostje postala češća $(56,1 \%$ sudionika dalo je krivi odgovor odgovorivši potvrdno na tu tvrdnju).

Da bismo dobili podatak o prosječnome znanju srednjoškolaca, prvo smo njihove odgovore rekodirali tako da su dobivali 1 bod za ispravan odgovor na skali znanja i 0 bodova za krivi odgovor ili odgovor "ne znam". Tako zbrojeni odgovori dali su rezultat u rasponu od 0 do 19. Prosječni postignuti rezultat bio je $M=9,95$ s raspršenjem $S D=4,11$. Najčešći postignuti rezultat bio je 12 , odnosno $63 \%$ riješenosti. Kad bismo postavili da je „prolazna ocjena" na takvoj skali 50\%, što je najčešći kriterij u školama, samo 53,8\% sudionika zadovoljilo bi taj kriterij.

Drugi istraživački problem bio je ispitati odnos percepcije zastupljenosti obrazovnih sadržaja o homoseksualnoj orijentaciji u školi i znanja srednjoškolaca o homoseksualnoj orijentaciji. Broj predmeta na kojima su učenici izjavili
Faculty of Philosophy, University of Zagreb. The respondents were given a contact point for questions and comments, and at the end of the questionnaire they were able to select and read educational material on homosexual orientation.

\section{RESULTS}

As part of the first research problem, we were interested in high school students' knowledge about homosexual orientation. Table 1 shows the frequency of choosing the correct and incorrect answers, and the answer "I do not know". The students showed the greatest uncertainty when replying to the statements Heterosexual teachers sexually abuse their students more often than homosexual teachers (50.3\% answered "I don't know"), and Historically, a significant number of homosexuals have made some major contributions to society. (51.3\% answered "I don't know"). The highest certainty (only $8.7 \%$ of the "I don't know" answers) was expressed with regard to the statement Homosexuals are easily recognized by their appearance, style or manner of expression. It is noteworthy, however, that most of them are sure of a completely wrong answer (only $41.7 \%$ answered correctly that the statement is false).

The highest percentage of correct answers was noted in the statement Homosexual men hate women and homosexual women hate men (85.6\% of the respondents answered correctly that this is not true), while the lowest percentage of correct answers was given in the statement Heterosexual teachers sexually abuse their students more often than homosexual teachers (24.7\% of the respondents answered correctly that this is not true). The highest percentage of incorrect answers was generated by the statement In the last 25 years, homosexuality 


\section{Tablica 1. Postotci ispravnih i neispravnih odgovora, te odgovora "Ne znam" na Skali znanja o homoseksualnoj orijentaciji $(N=312)$}

Table 1. Percentages of correct and incorrect answers, and "I don't know" answers, on the Knowledge of Sexual Orientation Scale $(N=312)$

\begin{tabular}{|c|c|c|c|}
\hline & $\mathbf{T} / \mathbf{T}$ & N/F & $\begin{array}{l}\text { Ne znam/ } \\
\text { Don't know }\end{array}$ \\
\hline $\begin{array}{l}\text { Za djecu koju odgajaju homoseksualni roditelji vjerojatnije je da će biti homoseksualne } \\
\text { orijentacije od one koju odgajaju heteroseksualni roditelji. (N) } \\
\text { Children raised by homosexual parents are more likely to be homosexual than those } \\
\text { raised by heterosexual parents. (F) }\end{array}$ & 56,1 & 22,4 & 21,5 \\
\hline $\begin{array}{l}\text { U posljednjih } 25 \text { godina homoseksualnost je postala češća. (N) } \\
\text { In the last } 25 \text { years, homosexuality has become more common. (F) }\end{array}$ & 25,6 & 56,1 & 18,3 \\
\hline $\begin{array}{l}\text { Većina homoseksualnih žena i muškaraca želi biti heteroseksualna. }(\mathrm{N}) \\
\text { Most homosexual women and men want to be heterosexual. }(\mathrm{F})\end{array}$ & 51,3 & 7,7 & 40,7 \\
\hline $\begin{array}{l}\text { Većina homoseksualaca želi nagovoriti ili privući druge u homoseksualni stil života. (N) } \\
\text { Most homosexuals want to persuade or attract others to homosexual lifestyle. (F) }\end{array}$ & 75,0 & 7,4 & 17,6 \\
\hline $\begin{array}{l}\text { Heteroseksualni profesori spolno zlostavljaju svoje učenike ili studente češće od } \\
\text { homoseksualnih profesora. (N) } \\
\text { Heterosexual teachers sexually abuse their students more often than homosexual } \\
\text { teachers. (F) }\end{array}$ & 24,7 & 25 & 50,3 \\
\hline $\begin{array}{l}\text { Povijesno gledano, značajan broj homoseksualaca napravio je neki veliki doprinos društvu. } \\
\text { (T) } \\
\text { Historically, a significant number of homosexuals have made some major contributions to } \\
\text { society. (T) }\end{array}$ & 33,3 & 15,4 & 51,3 \\
\hline $\begin{array}{l}\text { U istospolnim vezama jedan će se partner uvijek ponašati "muževnije", a drugi } \\
\text { „ženstvenije". (N) } \\
\text { In same-sex relationships, one partner will always behave "more masculine" and the other } \\
\text { "more feminine". (F) }\end{array}$ & 30,8 & 41,7 & 27,6 \\
\hline $\begin{array}{l}\text { Kad bi mediji pozitivno prikazivali homoseksualnost, to bi utjecalo na mlade te bi češće } \\
\text { postajali homoseksualci. (N) } \\
\text { If the media portrayed homosexuality positively, it would affect young people and make } \\
\text { them more homosexual. (F) }\end{array}$ & 51,3 & 25,6 & 22,8 \\
\hline $\begin{array}{l}\text { Homoseksualce je lako prepoznati prema izgledu, stilu ili načinu izražavanja. (N) } \\
\text { Homosexuals are easily recognized by their appearance, style or manner of expression. (F) }\end{array}$ & 41,7 & 49,7 & 8,7 \\
\hline $\begin{array}{l}\text { Homoseksualci koji žive s istospolnim partnerom uglavnom su jednako sretni ili sretniji od } \\
\text { heteroseksualnih bračnih parova. (T) } \\
\text { Homosexuals living with same-sex partners are generally just as happy as or happier than } \\
\text { heterosexual married couples. (T) }\end{array}$ & 56,4 & 13,5 & 30,1 \\
\hline $\begin{array}{l}\text { Homoseksualci nisu dobri uzori za djecu i mogli bi im psihološki naštetiti, kao i utjecati na } \\
\text { normalan spolni razvoj. (N) } \\
\text { Homosexuals are not good role models for children and could psychologically harm them } \\
\text { and affect their normal sexual development. (F) }\end{array}$ & 68,3 & 17,6 & 14,1 \\
\hline $\begin{array}{l}\text { Uzrok homoseksualne orijentacije jako je kompleksno pitanje na koje trenutno nema } \\
\text { odgovora. (T) } \\
\text { The cause of homosexual orientation is a very complex question to which there is } \\
\text { currently no answer. }(\mathrm{T})\end{array}$ & 44,2 & 26,3 & 29,5 \\
\hline $\begin{array}{l}\text { Ljudi postaju homoseksualcima ako su bili spolno zlostavljani kao djeca. (N) } \\
\text { People become homosexual if they were sexually abused as children. (F) }\end{array}$ & 75,3 & 3,2 & 21,2 \\
\hline
\end{tabular}




\begin{tabular}{|c|c|c|c|}
\hline $\begin{array}{l}\text { Homoseksualci će vjerojatnije zlorabiti droge ili alkohol od heteroseksualaca. (N) } \\
\text { Homosexuals are more likely to abuse drugs or alcohol than heterosexuals. (F) }\end{array}$ & 73,7 & 6,4 & 19,9 \\
\hline $\begin{array}{l}\text { Homoseksualci češće mijenjaju seksualne partnere od heteroseksualaca. (N) } \\
\text { Homosexuals change sexual partners more often than heterosexuals do. (F) }\end{array}$ & 42,6 & 12,5 & 44,9 \\
\hline $\begin{array}{l}\text { Homoseksualni muškarci mrze žene i homoseksualne žene mrze muškarce. (N) } \\
\text { Homosexual men hate women and homosexual women hate men. (F) }\end{array}$ & 85,6 & 2,2 & 12,2 \\
\hline $\begin{array}{l}\text { Homoseksualne osobe češće su zaražene HIV-om i drugim spolnim bolestima od } \\
\text { heteroseksualnih osoba. }(\mathrm{N}) \\
\text { Homosexuals are more likely to be infected with HIV and other sexually transmitted } \\
\text { diseases than heterosexuals. (F) }\end{array}$ & 28,8 & 30,1 & 41,0 \\
\hline $\begin{array}{l}\text { Osoba može odabrati želi li biti homoseksualne orijentacije. (N) } \\
\text { A person can choose whether they want to be homosexual. (F) }\end{array}$ & 57,7 & 29,2 & 13,1 \\
\hline $\begin{array}{l}\text { Seksualna se orijentacija može promijeniti terapijom, molitvom ili lijekovima. (N) } \\
\text { Sexual orientation can be changed by therapy, prayer, or medication. (F) }\end{array}$ & 72,4 & 9,0 & 18,6 \\
\hline
\end{tabular}

Napomena: lako su sudionici odgovarali s „točno“ i „netočno”, u tablici su za lakše razumijevanje rekodirani rezultati tako da stupac T predstavlja odgovore koji su donosili 1 bod. U zagradi, uz svaku tvrdnju, navedena je točnost odgovora.

Note: Although the respondents answered with "true" and "false", the results have been recoded in the table for easier understanding so that column $\mathrm{T}$ represents the answers that yielded 1 point. The accuracy of each statement is given in parentheses.

da su čuli nešto o homoseksualnoj orijentaciji, kretao se u rasponu od 0 do 8 , a najviše sudionika odabralo je samo jedan predmet. Na slici 1 prikazano je detaljno na koliko su predmeta sudionici rekli da su se susreli s tom temom.

lako je većina sudionika rekla da je barem na jednom predmetu slušala o toj temi, analiza odgovora na pitanje, jesu li tijekom nastave slušali o homoseksualnoj orijentaciji, pokazuje da je to uglavnom bilo neslužbeno ili da su se samo površno dotaknuli teme na nastavi. Detaljni rezultati prikazani su u tablici 2. Samo $13,5 \%$ sudionika imalo je cijeli školski sat posvećen temi, a 2,9\% neko dodatno predavanje ili radionicu.

Pitali smo sudionike na kojim su sve predmetima slušali o tome i ponudili smo na izbor osam predmeta u sklopu kojih se ta tema može očekivati. Ponudili smo i rubriku "Ostalo", ali je vrlo mali postotak sudionika spominjao predmete koji nisu bili ponuđeni, odnosno manje od $1 \%$ sudionika. Rezultati za ponuđene predmete nalaze se $\mathrm{u}$ tablici 3 . has become more common (56.1\% of the respondents answered incorrectly by considering this statement to be true).

To obtain data on the average knowledge of high school students, we first recoded their answers by giving them 1 point for a correct answer on the knowledge scale and 0 points for an incorrect or "I don't know" answer. The summed answers produced results ranging from 0 to 19. The average achieved result was $M=9.95$ with the dispersion $S D=4.11$. The most common result was 12 , or $63 \%$ of correct answers. If we set the "passing grade" on this scale to $50 \%$, which is the most common criterion in schools, only $53.8 \%$ of the respondents would meet this criterion.

The second research problem was to examine the relationship between the perception of presence of educational content on homosexual orientation in school and high school students' knowledge about homosexual orientation. The number of subjects that dealt with homosexual orientation, according to students, ranged from 0 to 8 . Most respondents 
Aleksandra Huić, Hana Greta Matković: Znanje srednjoškolaca o homoseksualnoj orijentaciji i sklonost...

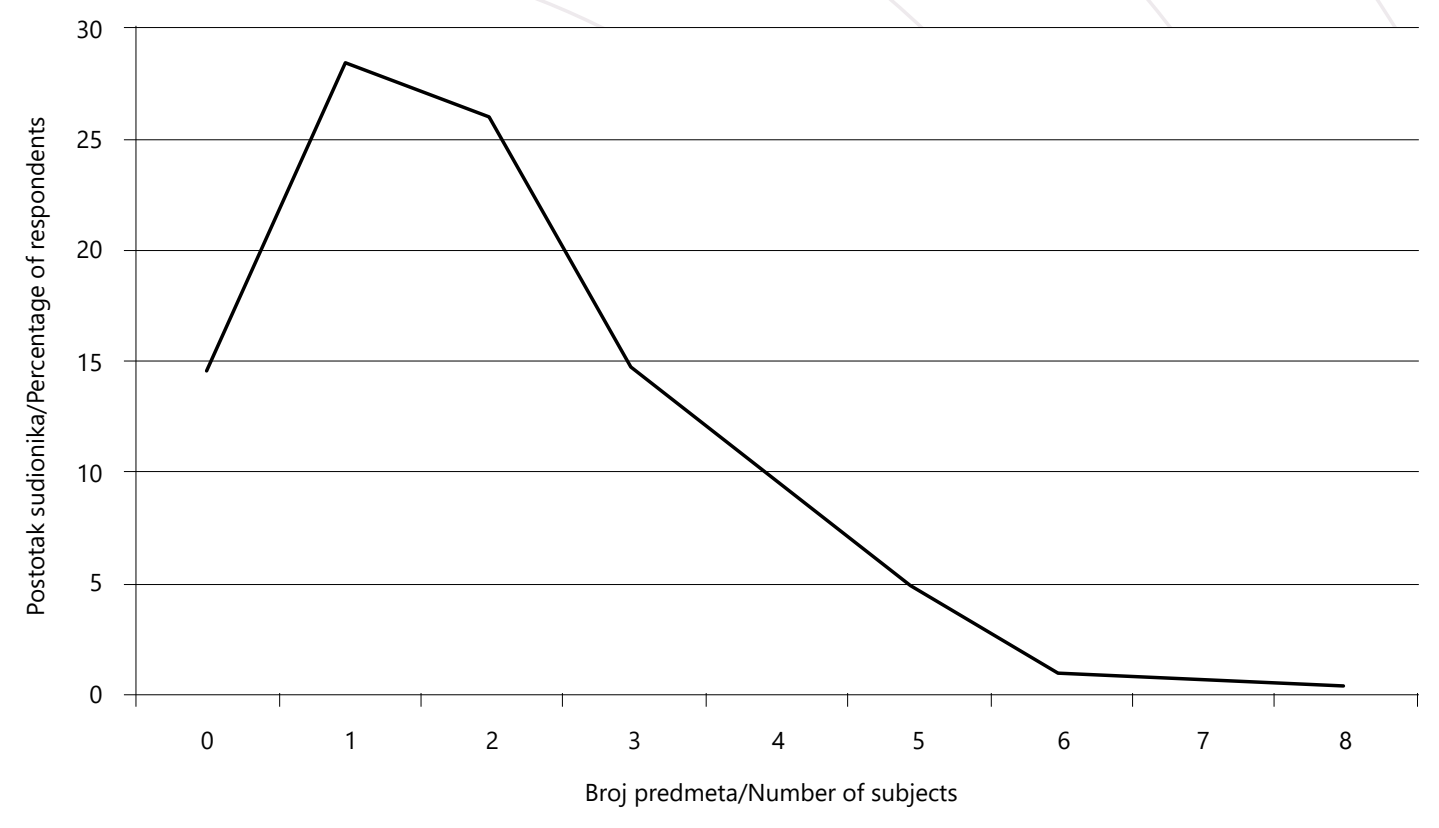

Slika 1. Postotci učenika prema broju predmeta na kojima su izjavili da su slušali o homoseksualnoj orijentaciji

Figure 1. Percentages of students by the number of subjects in which they stated that they had heard about homosexual orientation

Da bismo provjerili je li znanje učenika povezano s time koliko su imali prilike u školi slušati o homoseksualnoj orijentaciji, izračunali smo korelacije među ukupnim rezultatima na znanju, broju predmeta na kojima su sudionici rekli da su imali priliku slušati o tome te njihovoj percepciji u kojoj su mjeri tijekom nastave čuli o tome. Povezanost među brojem predmeta, na kojima su sudionici izjavili da su imali priliku slušati o homoseksualnosti i znanjem, nije se pokazala značajnom $(r=-0,013, p>0,05)$, kao ni povezanost $s$ percepcijom u kojoj su mjeri čuli o tome $(r=0,031, p>0,05)$. Neznačajne povezanosti upozoravaju na to da nismo potvrdili svoje hipoteze vezane uz odnos percepcije izloženosti o homoseksualnosti u obrazovnom programu iznanja o homoseksualnoj orijentaciji.

U sklopu tog problema zanimalo nas je još postoje li neke razlike s obzirom na to pohađaju li učenici nastavu iz etike ili vjeronauka. Izračunali smo t-test da provjerimo postoji li razlika u znanju između tih dviju skupina, a indicated only one subject. The Figure 1 shows in detail the number of subjects in which the respondents said they had encountered this topic.

Although most respondents said that they had heard about this topic in at least one subject, an analysis of the answers about whether they had heard about homosexual orientation during class shows that it was mostly unofficial, or that they touched on the topic only superficially. Detailed results are shown in Table 2. Only $13.5 \%$ of the respondents had an entire school period dedicated to the topic, and $2.9 \%$ had some additional lecture or workshop.

The respondents were asked in which subjects they had heard about this topic, with 8 subjects offered to choose from where this topic can be expected. The column "Other" was also offered, but a very small percentage of the respondents (less than $1 \%$ ) listed subjects that were not offered. The results for the offered subjects are given in Table 3. 
Tablica 2. Postotci odgovora na pitanje: Jeste li tijekom redovne nastave u školi slušali predavanja o homoseksualnosti? ( $N=312)$

Table 2. Percentages of answers to the question Have you attended lessons on the topic of homosexuality during regular school classes?

$(N=312)$

\begin{tabular}{|l|l|}
\hline $\begin{array}{l}\text { Nikad se ta tema nije spominjala na nastavi. } \\
\text { This topic was never mentioned in class. }\end{array}$ & 21,0 \\
\hline $\begin{array}{l}\text { Ponekad smo o tome raspravljali na nastavi iako to nije bilo službeno. } \\
\text { Sometimes we discussed it in class, but it wasn't official. }\end{array}$ & 40,0 \\
\hline $\begin{array}{l}\text { Dotaknuli smo se površno te teme u sklopu nastavnoga gradiva. } \\
\text { We touched on this topic superficially as part of the curriculum. }\end{array}$ & 22,6 \\
\hline $\begin{array}{l}\text { Imali smo cijeli školski sat posvećen toj temi. } \\
\text { We had a whole period dedicated to that topic. }\end{array}$ & 13,5 \\
\hline $\begin{array}{l}\text { Imali smo dodatna predavanja o toj temi (npr. u našoj školi su održana predavanja o diskriminaciji homoseksualnih } \\
\text { osoba). } \\
\text { We had additional lectures on this topic (e.g. lectures on discrimination against homosexuals were held in our school). }\end{array}$ & 2,9 \\
\hline
\end{tabular}

Tablica 3. Postotak sudionika koji su slušali o homoseksualnosti na pojedinom predmetu $(N=312)$

Table 3. Percentage of the students who have heard about the topic of homosexuality in a particular school subject $(N=312)$

\begin{tabular}{|c|c|}
\hline Vjeronauk / Religious education & 44,9 \\
\hline Biologija / Biology & 33 \\
\hline Etika / Ethics & 33 \\
\hline Psihologija / Psychology & 24,4 \\
\hline Hrvatski jezik / Croatian language & 19,9 \\
\hline Strani jezik / Foreign language & 19,2 \\
\hline Sociologija / Sociology & 13,5 \\
\hline Filozofija / Philosophy & 3,8 \\
\hline
\end{tabular}

rezultati t-testa prikazani su na slici 2. Razlika između tih dviju skupina pokazala se statistički značajnom; bolje znanje imali su učenici koji su pohađali etiku nego oni koji su pohađali vjeronauk ( $t=4,87, p<.001)$, što je nalaz koji je potvrdio našu početnu hipotezu.

U sklopu trećeg problema zanimalo nas je postoji li povezanost između znanja o homoseksualnoj orijentaciji i sklonosti diskriminaciji homoseksualnih osoba. Pritom smo analizirali i koji je postotak sudionika davao diskriminirajuće
To check whether the students' knowledge was related to the opportunities they had to hear about the topic of homosexual orientation in school, we calculated correlations between the overall knowledge score, the number of subjects in which the respondents said they had heard about the topic, and their perceptions as to what extent they had heard about the topic during class. The correlation between the number of subjects in which the respondents said they had heard about the topic of homosexuality and their knowledge 
Aleksandra Huić, Hana Greta Matković: High school students' knowledge about homosexual orientation...

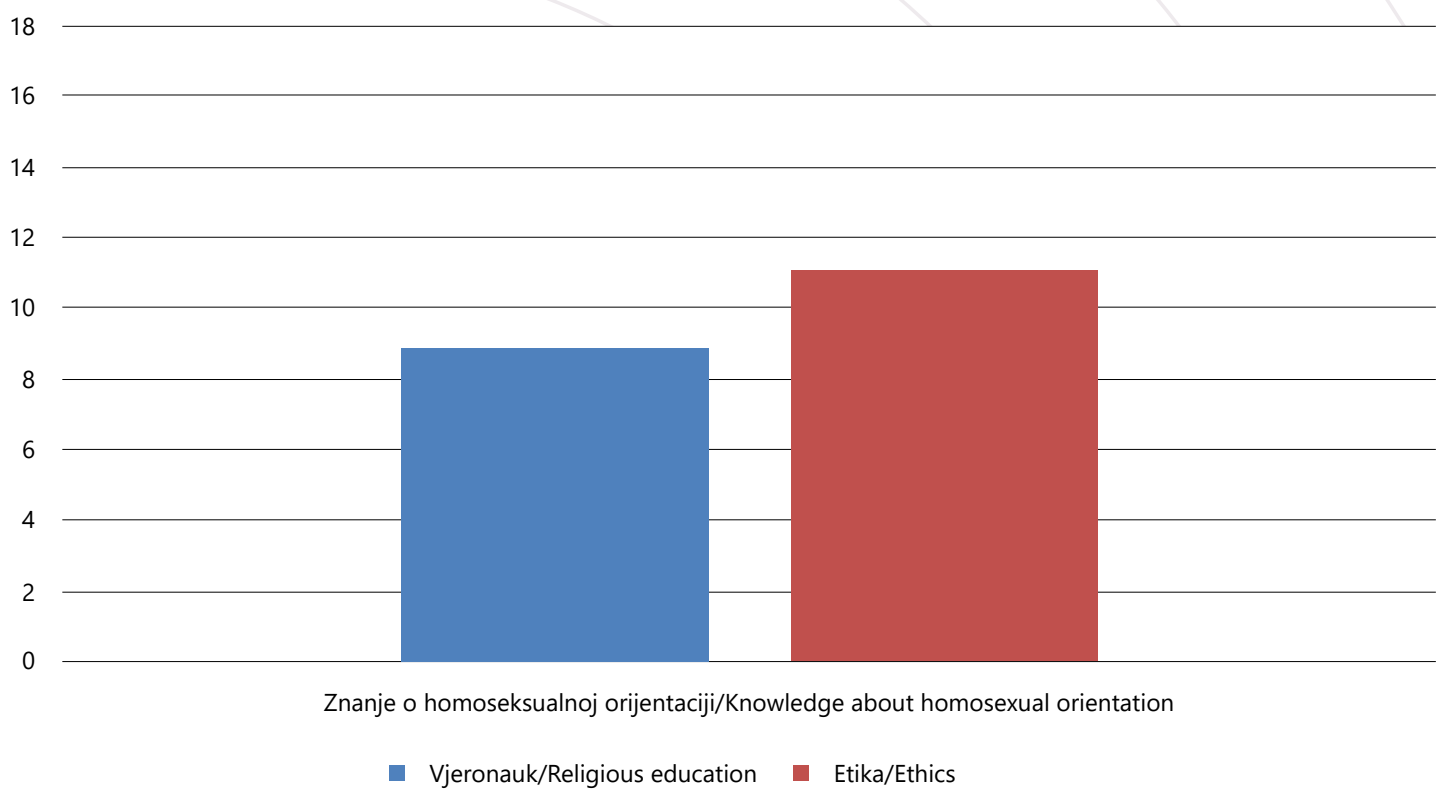

Slika 2. Razlika u znanju o homoseksualnoj orijentaciji među učenicima koji pohađaju nastavu iz vjeronauka i nastavu iz etike

Figure 2. Difference in knowledge about homosexual orientation between students attending religious education and ethics classes

odgovore na pojedine čestice, a ti rezultati detaljno su prikazani u tablici 5.

U prosjeku su sudionici potvrdno odgovorili na jednu od 12 diskriminirajućih tvrdnji $(M=1,23, S D=2,06)$, što upozorava na učenikov nizak stupanj sklonosti diskriminaciji homoseksualnih osoba. Međutim, kada se analiziraju odgovori na pojedine tvrdnje, vidi se da su u nekim slučajevima značajni postotci učenika skloni diskriminirati homoseksualne osobe. Čak 35,9\% sudionika sklono je diskriminirati homoseksualne osobe u slučaju dijeljenja sobe, dok je najmanji broj sudionika $(2,2 \%)$ sklon diskriminaciji homoseksualnog učitelja ili učiteljice. Petina bi sudionika (22,1\%) homoseksualnim osobama zabranila tjelesni kontakt na javnim mjestima. Ono što je također zanimljivo jest da bi manje sudionika uključilo homoseksualnu osobu u vlastitu skupinu za školski projekt $(86,2 \%)$ nego što bi tražilo pomoć od homoseksualnog kolege/kolegice na školskom zadatku (94,9\%). did not prove significant $(r=-0.013, p>0.05)$, nor did the correlation with the perceptions as to what extent they heard about the topic ( $r=0.031, p>0.05)$. Insignificant correlations indicate that our assumptions about the relationship between the perception of exposure to the topic of homosexuality in the curriculum and knowledge about homosexual orientation were not confirmed.

As part of this problem, we were also interested in whether there were any differences with regard to whether students attend classes in ethics or religious education. We calculated the $t$-test to check if there was a difference in knowledge between these two groups, with the results shown in Figure 2. The difference between these two groups proved to be statistically significant, with better knowledge possessed by students who attended ethics than those who attended religious education $(t=4.87, p<.001)$, a finding that confirmed our initial assumption. 


\section{Tablica 5. Postotak diskriminirajućih odgovora prema pojedinoj čestici skale sklonosti diskriminaciji $(N=312)$}

\section{Table 5. Percentage of discriminatory answers per particular statement of the discrimination} tendency scale $(N=312)$

\begin{tabular}{|c|c|}
\hline & $\begin{array}{l}\text { Odgovor "Da" } \\
\text { Answer "Yes" }\end{array}$ \\
\hline $\begin{array}{l}\text { Da biram suradnika za važan školski projekt, radije bih odabrao/la heteroseksualnu osobu nego } \\
\text { homoseksualnu osobu } \\
\text { If I were to choose a partner for an important school project, I would rather choose a heterosexual than a } \\
\text { homosexual person. }\end{array}$ & 13,8 \\
\hline $\begin{array}{l}\text { Da na satu ne mogu riješiti neki važan zadatak, radije bih tražio/la pomoć kolege/ice heteroseksualne } \\
\text { orijentacije nego kolege/ice homoseksualne orijentacije. } \\
\text { If I could not solve an important task in class, I would rather seek the help of a heterosexual than a } \\
\text { homosexual schoolmate. }\end{array}$ & 5,1 \\
\hline $\begin{array}{l}\text { Na izborima ne bih dao/dala svoj glas homoseksualnom kandidatu/ kandidatkinji, iako ima iste kvalifikacije i } \\
\text { iskustvo kao i heteroseksualni kandidati. } \\
\text { I would not vote for a homosexual candidate in an election, even though he/she may have the same } \\
\text { qualifications and experience as heterosexual candidates. }\end{array}$ & 14,1 \\
\hline $\begin{array}{l}\text { Da trebam izabrati suigrača za svoju sportsku ekipu, radije bih odabrao/la heteroseksualnu osobu, čak i ako je } \\
\text { homoseksualac bolji u tom sportu. } \\
\text { If I were to choose a teammate for my sports team, I would rather choose a heterosexual person, even if a } \\
\text { homosexual is better in that sport. }\end{array}$ & 4,8 \\
\hline $\begin{array}{l}\text { Na putovanju bih radije dijelio/la sobu s heteroseksualnom, nego s homoseksualnom osobom mojeg spola. } \\
\text { On a trip, I would rather share a room with a heterosexual than a homosexual person of my gender. }\end{array}$ & 35,9 \\
\hline $\begin{array}{l}\text { Da saznam da je moj liječnik homoseksualac, promijenio/la bih liječnika. } \\
\text { If I found out that my doctor was homosexual, I would change the doctor. }\end{array}$ & 10,6 \\
\hline $\begin{array}{l}\text { Da saznam da mi je učitelj/ica homoseksualne orijentacije, tražio/la bih roditelje da me prebace u neki drugi } \\
\text { razred. } \\
\text { If I found out that my teacher was homosexual, I would ask my parents to transfer me to another class. }\end{array}$ & 2,2 \\
\hline $\begin{array}{l}\text { Da saznam da je netko od mojih prijatelja homoseksualne orijentacije, prestao/ala bih se družiti s njim/njom. } \\
\text { If I found out that one of my friends was homosexual, I would stop hanging out with him/her. }\end{array}$ & 3,8 \\
\hline $\begin{array}{l}\text { Da saznam da je sportaš/ica za kojeg/u navijam homoseksualne orijentacije, ne bih više navijao/la za nju/ } \\
\text { njega. } \\
\text { If I found out that an athlete I support was homosexual, I would stop supporting him/her. }\end{array}$ & 3,5 \\
\hline $\begin{array}{l}\text { Da saznam da je moj/a najdraži/a pjevač/ica homoseksualne orijentacije, prestao/la bih ga slušati. } \\
\text { If I found out that my favorite singer was homosexual, I would stop listening to him/her. }\end{array}$ & 2,6 \\
\hline $\begin{array}{l}\text { Da saznam da je u nekom društvu homoseksualna osoba, maknuo/la bih se iz tog društva. } \\
\text { If I found out that there was a homosexual person in a group of people, I would move away from their } \\
\text { company. }\end{array}$ & 4,5 \\
\hline $\begin{array}{l}\text { Zabranio/la bih homoseksualnim osobama tjelesni kontakt na javnim mjestima. } \\
\text { I would ban homosexuals from having physical contact in public. }\end{array}$ & 22,1 \\
\hline
\end{tabular}

\section{U skladu s postavljenom hipotezom, zna-} nje o homoseksualnoj orijentaciji i sklonosti diskriminaciji homoseksualnih osoba značajno je negativno povezano $(\mathrm{N}=312 ; \mathrm{r}=-0.601 ; \mathrm{p}<$ $0.01)$, odnosno $36 \%$ varijance $u$ rezultatima na
As part of the third research problem, we were interested in whether there was a connection between knowledge about homosexual orientation and the tendency to discriminate against homosexual persons. We also analyzed 
upitniku sklonosti diskriminaciji objašnjeno je rezultatom na skali znanja $\left(R^{2}=0,36\right)$. Učenici s više znanja o homoseksualnoj orijentaciji manje su skloni diskriminirati osobe homoseksualne orijentacije.

U sklopu četvrtog problema zanimalo nas je hoće li učenici odabrati čitanje dodatnog materijala o homoseksualnoj orijentaciji i time proširiti svoje znanje, i ovisi li ta odluka o njihovu postojećem znanju o homoseksualnoj orijentaciji i sklonosti diskriminaciji homoseksualnih osoba. Unatoč velikome postotku odgovora " $\mathrm{Ne}$ znam" na pitanjima iz znanja, samo je 44,56\% učenika odabralo pročitati dodatni edukacijski materijal. U skladu s postavljenom hipotezom, oni učenici koji su u startu imali bolje znanje ( $\mathrm{t}=3,708 ; \mathrm{p}<0.01)$ i koji su manje skloni diskriminaciji $(t=-4,48, p<0,01)$ češće su $i$ birali pročitati dodatni edukacijski materijal (vidi sliku 3).

\section{RASPRAVA}

U ovom istraživanju bavili smo se znanjem srednjoškolaca o homoseksualnoj orijentaciji, načinom na kojije ono povezano s percepcijom zastupljenosti sadržaja o toj temi u obrazovnom programu te kakva je sklonost srednjoškolaca diskriminirati osobe homoseksualne orijentacije i je li to povezano sa znanjem.

Znanje srednjoškolaca ispitanih u ovom istraživanju o homoseksualnoj orijentaciji pokazalo se slabim, odnosno jedva za prolaznu ocjenu. Naši su rezultati u skladu s rezultatima drugih istraživanja o toj temi u Hrvatskoj (Bagić i Gvozdanović, 2015; Bovan i Širinić, 2016), kojima je dobiveno da oko polovice maturanata također nema osnovna znanja o uzrocima homoseksualne orijentacije. Dodatno, ovo istraživanje ispitalo je znanje srednjoškolaca od prvog do četvrtog razreda (ne samo maturanata), i to the percentage of the respondents who gave discriminatory answers to particular statements, and these results are shown in detail in Table 5.

On average, the respondents answered in the affirmative to one of the 12 discriminatory statements $(M=1.23, S D=2.06)$, indicating the students' low degree of tendency to discriminate against homosexuals. However, when analyzing answers to particular statements, it is evident that in some cases significant percentages of the students tend to discriminate against homosexuals. As many as $35.9 \%$ of the respondents tend to discriminate against homosexuals in the case of room sharing, while the smallest number of the respondents (2.2\%) tend to discriminate against a homosexual teacher. One-fifth of the respondents (22.1\%) would ban homosexuals from having physical contact in public. Additionally, fewer respondents would include a homosexual person in their own group for a school project (86.2\%) than would seek help from a homosexual schoolmate on a school assignment (94.9\%).

In keeping with the research assumption, knowledge about homosexual orientation and tendency to discriminate against homosexuals were significantly negatively related $(\mathrm{N}=312$; $r=-0.601 ; p<0.01)$, i.e. $36 \%$ of the variance in the results on the tendency to discriminate questionnaire was explained by the result on the knowledge scale $\left(R^{2}=0.36\right)$. The students with more knowledge about homosexual orientation are less likely to discriminate against homosexuals.

As part of the fourth research problem, we were interested in whether the students would choose to read additional material on the topic of homosexual orientation and thus expand their knowledge and whether this decision depended on their existing knowledge about the topic and the tendency to discriminate against homosexuals. Despite a high percentage of "I 


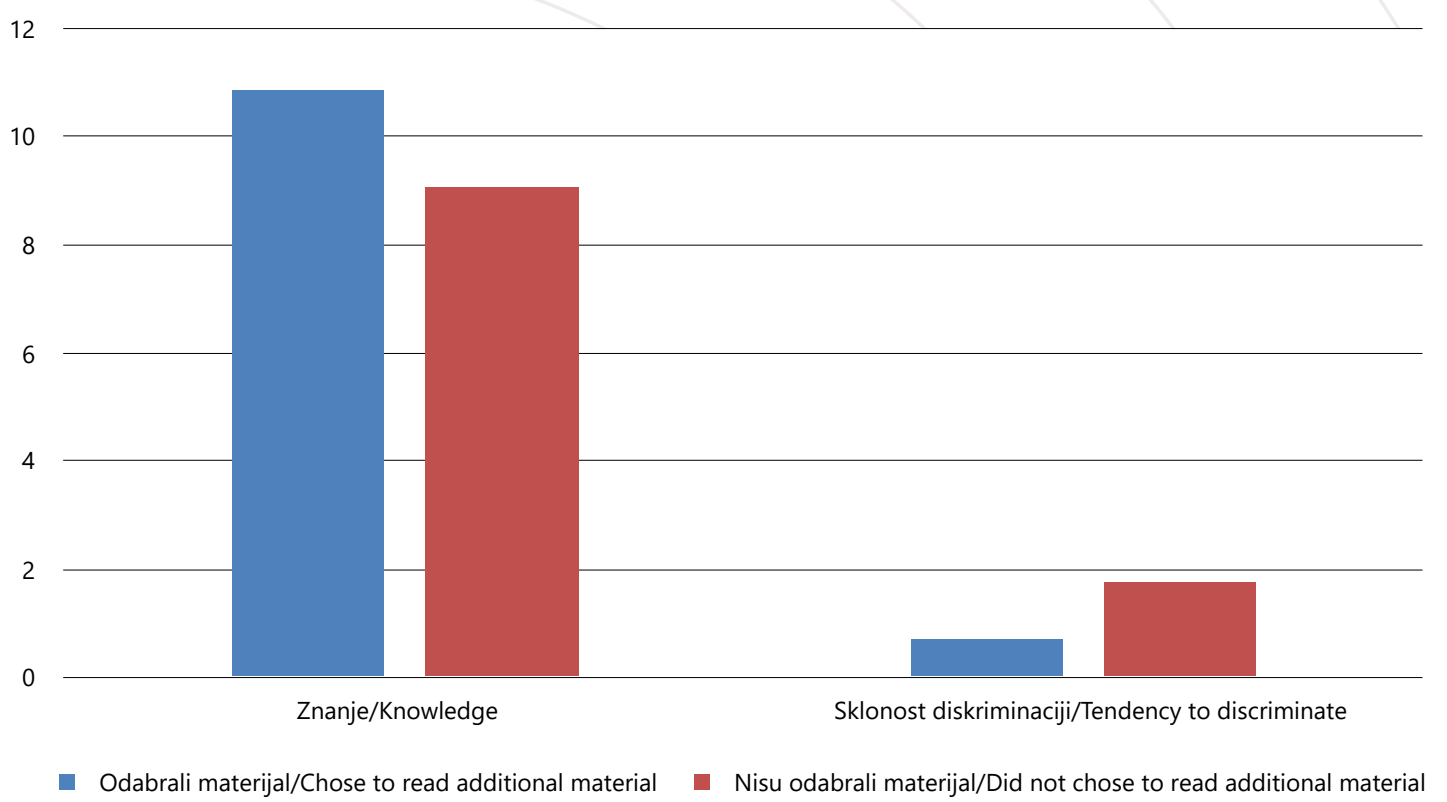

Slika 3. Razlika u znanju o homoseksualnoj orijentaciji i sklonosti diskriminaciji homoseksualnih osoba među učenicima koji su odabrali pročitati dodatni materijal o temi $i$ onih koji nisu odabrali taj materijal

Figure 3. Difference in knowledge about homosexual orientation and tendency to discriminate against homosexuals between the students who chose to read additional material on the topic and those who did not choose to read such material

na sveobuhvatniji način u odnosu na prijašnja istraživanja, te time produbilo spoznaje o znanju srednjoškolaca o homoseksualnoj orijentaciji, kao i o njihovoj sigurnosti u znanje o toj temi.

Učenici su općenito bili točniji i sigurniji u tvrdnjama koje se tiču toga ugrožava li homoseksualnost na neki način heteroseksualan stil života ili pojedince. Također, pokazuju više znanja u tvrdnjama koje se tiču uzroka homoseksualnosti, što je zanimljivo s obzirom na to da se u sklopu službenog kurikula nigdje eksplicitno ne govori o tome da homoseksualnost nije izbor. $S$ druge strane, to je rečenica koja se možda najčešće ističe u kampanjama za suzbijanje homofobije, pa su možda sudionici tim informacijama bili izloženiji izvan obrazovnog sustava.

Najviši postotak krivih odgovora sudionici su dali na tvrdnju $U$ posljednjih 25 godina homoseksualnost je postala češća. Više od pola sudionika misli da je to istina, što može imati don't know" answers to the questions about their knowledge, only $44.56 \%$ of the students chose to read additional educational material. In keeping with the research assumption, those students who had better knowledge in the beginning ( $t=3.708 ; p<0.01)$ and who are less prone to discrimination $(t=-4.48, p<0.01)$ also chose to read additional educational material more frequently (see Figure 3).

\section{DISCUSSION}

This study addressed high school students' knowledge about homosexual orientation, its relation to the perception of the presence of content on this topic in the curriculum, and the tendency of high school students to discriminate against homosexuals, including whether it is related to their knowledge. 
različite uzroke. Za početak, svi sudionici imali su između 14 i 20 godina, od čega većina 16. Možemo pretpostaviti da se barem kod nekih od njih pojavljuje pristranost zbog toga što je u njihovim životima ta tema aktualnija zadnjih nekoliko godina. Također, u sklopu službenog kurikula tema homoseksualnosti nije uključena u nastavu iz povijesti i samo je petero sudionika izjavilo da su čuli nešto o toj temi na nastavi povijesti. Drugim riječima, nisu bili izloženi informacijama o homoseksualnoj orijentaciji tijekom povijesti, o prihvaćanju u različitim kulturama tijekom stoljeća, o prvim i važnijim pokretima za zaštitu prava ili sličnim informacijama koje bi im pomogle spoznati širi povijesni kontekst.

Osim postotaka točnih i krivih odgovora, informativni su i učenički odgovori "Ne znam". Oni nam mogu pokazati neke nedostatke $u$ obrazovnom programu, a i upozoriti na neke opasnosti. Primjerice, posebno je važna tvrdnja Homoseksualce je lako prepoznati prema izgledu, stilu ili načinu izražavanja na koju je najmanje sudionika odgovorilo odgovorom "Ne znam". lako pokazuju sigurnost u svoj odgovor na tom pitanju, manje od pola sudionika odgovorilo je ispravno da ta tvrdnja nije točna, a više njih odgovorilo je krivo. Na krivo znanje učenika o mogućnosti lakoga prepoznavanja homoseksualnih pojedinaca vjerojatno utječu mediji. U serijama i filmovima često je vrlo jednostavno prepoznati homoseksualne likove. Muškarci uglavnom imaju specifičan način govora, "napadan" modni izričaj, bave se stereotipnim profesijama (plesači, frizeri, glumci, itd.) i često popune ulogu "gej najboljeg prijatelja" (npr. Opasne djevojke, Moj dečko se ženi, Will \& Grace, Glee, Seks i grad, Riverdale). Žene su uglavnom odjevene stereotipno muževnije, govore dubljim glasom, imaju kraću kosu i kretnje im nisu tradicionalno feminine (Igra prijestolja, Kako sam upoznao vašu majku, Narančasta je nova crna, Ženske priče). Kada su homoseksualni likovi prikazani u paru,
The knowledge of the high school students surveyed in this study on homosexual orientation proved to be poor, barely for a passing grade. Our findings are in line with the findings of other research on this topic in Croatia (Bagić and Gvozdanović, 2015; Bovan and Širinić, 2016), which has shown that about half of high school graduates lack basic knowledge about the causes of homosexual orientation. In addition, this study examined the knowledge of high school students from first to fourth grade (not just high school graduates), in a more comprehensive way compared to previous research, and thus deepened the awareness about high school students' knowledge of homosexual orientation, as well as their confidence in the knowledge about this topic.

The students were generally more accurate and confident in the statements about whether homosexuality in some way threatened the heterosexual lifestyle or individuals. They also showed more knowledge in the statements concerning the causes of homosexuality, which is interesting given that the official curriculum does not explicitly state that homosexuality is not a choice. On the other hand, this sentence is perhaps most often highlighted in campaigns to combat homophobia, and the respondents may have been more exposed to this information outside the education system.

The respondents provided the highest percentage of incorrect answers to the statement in the last 25 years, homosexuality has become more common. More than half of the respondents believe this is true, which can have different causes. First of all, all respondents were between 14 and 20 years old, and most of them 16. We can assume that at least some of them are biased because this topic has become more relevant in their lives in the last few years. Moreover, the topic of homosexuality is not included in history teaching as part of the 
često je jedan dio para maskuliniji a drugi dio femininiji, što je možda povezano s time da je na tvrdnju $U$ istospolnim vezama jedan će se partner uvijek ponašati 'muževnije', a drugi 'ženstvenije' gotovo pola učenika odgovorilo krivo, a još četvrtina da ne zna. U popularnoj kulturi raširen je i pojam "gejdar", složenica riječi "gej" i "radar" koja znači da postoji metoda ili urođena sposobnost za prepoznavanje homoseksualnih osoba. Istraživanja su pokazala da je "gejdar" izrazito netočan, koliko god ispitanici u istraživanjima bili sigurni u njegovo postojanje i svoju sposobnost (Cox, Devine, Bischmann i Hyde, 2017). Takva reprezentacija u medijima i perpetuiranje stereotipa kao što su "butch lezbijka”, "gej najbolji prijatelj” i "gejdar" vjerojatno su pridonijeli takvim rezultatima, no ono što je posebno opasno $u$ dobivenim brojkama je da su sudionici bili najuvjereniji upravo u te odgovore.

U sklopu drugoga istraživačkog problema zanimalo nas je na koji način je znanje o homoseksualnoj orijentaciji povezano s percepcijom zastupljenosti teme u obrazovnom sustavu. Pretpostavili smo da će oni koji izjavljuju da su u školi više slušali o homoseksualnosti imati i bolje znanje, no ta povezanost nije se pokazala statistički značajnom, te nismo potvrdili svoju hipotezu. lako su sudionici pisali da su spominjali tu temu na čak osam predmeta, zapravo se pokazalo da je većina nešto slušala na jednom do dva predmeta. Sam broj predmeta ne mora značiti da su učenici čuli značajnu količinu informacija o temi pa je moguće da iz tog razloga nismo dobili značajnu povezanost. Takva interpretacija u skladu je s našim nalazom da većina srednjoškolaca izjavljuje da je, ako i jesu na nastavi spominjali tu temu, to bilo uglavnom neslužbeno na satu ili samo površno. Manjina (13,5\%) je izjavila da su imali cijeli sat posvećen baš homoseksualnoj orijentaciji. official curriculum, and only five respondents stated that they had heard something about it in history classes. In other words, they had not been exposed to information about homosexual orientation throughout history, its acceptance in different cultures through centuries, about the first and more important rights movements, or similar information that would help them understand the broader historical context.

Along with the percentages of correct and incorrect answers, it is the "I don't know" answers that are instructive as well. They may point at shortcomings in the curriculum, but also indicate some dangers. For instance, the statement Homosexuals are easily recognized by their appearance, style or manner of expression, which is particularly important, is where the fewest respondents answered "I don't know". Although they appear confident in answering it, less than half of the respondents answered correctly that the statement is not true, and more of them answered incorrectly. The students' misconceptions about the possibility to easily recognize homosexuals are likely influenced by the media. In films and TV series, it is often very easy to recognize homosexual characters. Men generally have a specific manner of speaking, "extravagant" appearance, engage in stereotypical professions (dancers, hairdressers, actors, etc.) and often fill the role of "gay best friend" (e.g. Mean Girls, My Best Friend's Wedding, Will \& Grace, Glee, Sex and the City, Riverdale). Women are mostly dressed stereotypically more masculine, speak in a deeper voice, have shorter hair and their movements are not traditionally feminine (Game of Thrones, How I Met Your Mother, Orange is the New Black, The L Word). When homosexual characters are portrayed as a couple, one of them is often more masculine and the other one more feminine, which may be related to the fact that almost half of the students answered incorrectly to the statement In same-sex relationships, one partner will always 
Od predmeta koje su sudionici spominjali, najviše in je o tome slušalo na vjeronauku, a na drugom su mjestu biologija i etika. Takvi rezultati konzistentni su s analizom udžbenika (Brumen, 2012) prema kojoj su to tri predmeta u kojima je tema zastupljenija, a i koje učenici imaju tijekom cijeloga srednjoškolskog obrazovanja. Zabrinjavajuće je koliko malo se o toj temi govori na psihologiji i sociologiji, s obzirom na to da su upravo to struke koje se najčešće bave znanošću povezanom sa specifičnostima roda i spola.

Na temelju analize udžbenika (Brumen, 2012) očekivali smo da će važnu ulogu u znanju srednjoškolaca imati podatak pohađaju li vjeronauk ili etiku kao školske predmete. $\mathrm{S}$ obzirom da je gradivo na vjeronauku vjerski obojeno i ne reflektira znanstvene činjenice o homoseksualnoj orijentaciji, postavili smo hipotezu da će učenici koji pohađaju vjeronauk imati lošije znanje od učenika koji pohađaju etiku. Naši rezultati potvrdili su postavljenu hipotezu; odnosno, učenici koji pohađaju vjeronauk imaju statistički značajno slabije znanje od onih koji pohađaju etiku. Takve rezultate možemo objasniti s nekoliko čimbenika. Za početak, analiza udžbenika (Brumen, 2012) pokazala je da udžbenik iz vjeronauka uglavnom pruža informacije o seksualnoj orijentaciji koristeći se religijskim tekstovima te time koliko je homoseksualnost s vjerske strane (ne)prihvatljiva, odnosno prikazuje se kao nešto neprirodno $\mathrm{i}$ grešno. U udžbeniku pravoslavnog vjeronauka ta se tematika uopće ne spominje, a na muslimanskom vjeronauku samo u 7. razredu osnovne škole opisana je kao prva seksualna nastranost (Brumen, 2012). U udžbeniku iz etike nalaze se konkretnije informacije koje služe i kao poticaj za raspravu na nastavi. Moguće da je dobivena razlika među učenicima posljedica informacija kojima su bili izloženi tijekom obrazovanja na tim dvama predmetima. behave "more masculine" and the other "more feminine", while another quarter did not know. The term "gaydar", a compound of the words "gay" and "radar", referring to a method or intuitive ability to recognize homosexuals, is also widespread in popular culture. Research has shown that "gaydar" is extremely unreliable, no matter how sure the respondents in the study were of its existence and their own ability (Cox, Devine, Bischmann, and Hyde, 2017). Such representation in the media and perpetuation of stereotypes such as "butch lesbian", "gay best friend" and "gaydar" probably contributed to these results, but what is especially dangerous in the findings is that the respondents were most convinced of these answers exactly.

As part of the second research problem, we were interested in how knowledge about homosexual orientation is related to the perception of the presence of this topic in the school curriculum. We assumed that those students who stated that they had heard more about homosexuality in school would have better knowledge, but this correlation did not prove to be statistically significant, so that our assumption was not confirmed. Although the respondents answered that this topic had been mentioned in up to as many as eight subjects, it actually turned out that most had heard something about it in one to two subjects. The number of subjects alone does not necessarily mean that the students have heard a significant amount of information on the topic, which may be the reason that we found no significant correlation. This interpretation is consistent with our finding that most high school students say that, if the topic was mentioned in class, it was mostly unofficially, or only superficially. A minority (13.5\%) stated that they had had a whole school period dedicated to the topic of homosexual orientation. 
Osim toga, moguće je i da je dobivena razlika posljedica razlika u stavovima srednjoškolaca koji nisu bili fokus ovog istraživanja. Naime, istraživanja konzistentno pokazuju razlike u stavovima prema homoseksualnim osobama s obzirom na religioznost (Whitley, 2009; Roggemans, Spruyt, Van Droogenbroeck i Keppens, 2015), odnosno da ljudi kojima je religija važnija u životu, imaju negativnije stavove prema homoseksualnosti. S obzirom na to da učenici vjerojatno biraju žele li pohađati vjeronauk ili etiku u skladu sa svojim početnim stavovima i stupnjem religioznosti, moguće je da su se učenici razlikovali u svojem znanju o temi i prije srednje škole.

Naš treći problem bavio se odnosom znanja o homoseksualnoj orijentaciji i sklonosti diskriminacije osoba homoseksualne orijentacije. lako se pokazalo da učenici općenito nisu posebno skloni diskriminirati homoseksualne osobe, što je pozitivan rezultat, detaljnija analiza pokazala je da bi značajan broj učenika bio spreman diskriminirati u određenim situacijama. Tako bi nešto više od petine učenika zabranilo homoseksualnim osobama kontakt na javnom mjestu, što je u skladu s nalazima istraživanja Bagić i Gvozdanović (2015) te Bovan i Širinić (2016). Najveći postotak diskriminirajućih odgovora dobila je tvrdnja Na putovanju bih radije dijelio/la sobu s heteroseksualnom nego s homoseksualnom osobom svojeg spola, odnosno čak trećina sudionika bi u toj situaciji dala prednost heteroseksualnoj osobi nad homoseksualnom. Najmanje postotke diskriminirajućih odgovora dobile su tvrdnje prema kojima bi se sudionik trebao odreći neke osobe iz svojeg života da je ta osoba homoseksualne orijentacije (npr. Da saznam da je moj/a najdraži/a pjevač/ica homoseksualne orijentacije, prestao/la bihje/ga slušati.). Oba rezultata konzistentna su s istraživanjem Huić, Jelić i Kamenov (2016) provedenim na odrasloj populaciji, a u kojem se postavlja teza da je tvrdnja s kime bi dijelili sobu primjer
Of the subjects the respondents mentioned, most of them heard about the topic in religious education, followed by biology and ethics. Such results are consistent with the textbook analysis (Brumen, 2012) according to which these are the three subjects in which the topic is more present, and which students have throughout secondary education. It is concerning how little this topic is mentioned in psychology and sociology, considering that these disciplines deal with the science related to the specifics of sex and gender the most.

Based on the textbook analysis (Brumen, 2012), we expected that an important role in high school students' knowledge would be played by whether they attend religious education or ethics as school subjects. Since school material in religious education is religiously colored and does not reflect the scientific facts about homosexual orientation, we assumed that students attending religious education would have poorer knowledge than students attending ethics. Our findings confirmed this assumption, i.e. students who attend religious education have statistically significantly poorer knowledge than those who attend ethics. We can explain these results with several factors. To begin with, the textbook analysis (Brumen, 2012) showed that the textbook on religious education mainly provides information on sexual orientation using religious texts, and about how (un)acceptable homosexuality is from the religious point of view, being presented as something unnatural and sinful. In the Orthodox religious education textbook, this topic is not mentioned at all, and in the Muslim religious education textbook only in the seventh grade of primary school, where it is described as the first sexual perversion (Brumen, 2012). The ethics textbook contains more specific information, which also serves as material for discussion in class. It is possible that the difference between students can be attributed to the information 
prikrivenog heteroseksizma pa da je zbog toga u metodi samoiskaza i manje podložna socijalno poželjnu odgovaranju. Također, navode da taj primjer vjerojatno jače izaziva emocionalne reakcije koje mogu biti u podlozi stereotipa i predrasuda prema homoseksualnim osobama (gađenje, ljutnja i strah) (Herek, 2004).

lako dosadašnja istraživanja nisu bila jednoznačna pri ustanovljenju povezanosti između znanja i sklonosti diskriminaciji (Cramwinckel, Scheepers i van der Toorn, 2018), ovim istraživanjem potvrdili smo svoju početnu hipotezu. Učenici sa slabijim znanjem istovremeno su bili skloniji diskriminirati osobe homoseksualne orijentacije. Taj je nalaz važan jer je sklonost diskriminaciji mjera namjere ponašanja, a koja je pak najvažniji prediktor pravog ponašanja (Ajzen, 1991). Dodatno, takav nalaz ponovno nas upozorava na opasnost krivih uvjerenja o homoseksualnoj orijentaciji. Škola, kao odgojno-obrazovna institucija, koja bi trebala obrazovati društveno odgovorne građane, ne samo da ima odgovornost unutar svojih zidova sprečavati nasilje i diskriminaciju na osnovi homoseksualne orijentacije nego i poučavati mlade točnim činjenicama o homoseksualnoj orijentaciji. Dakle, naši nalazi upozoravaju da stečeno znanje ima potencijal doprinositi smanjivanju diskriminacije homoseksualnih osoba. Zato je potrebno da se ta tema, kao i općenito teme vezane uz seksualnost, prestanu izbjegavati u školama. Nadamo se da će kurikuli međupredmetnih tema Osobni i socijalni razvoj, Zdravlje i Građanski odgoj i obrazovanje, koji su se u sklopu kurikulske reforme počeli primjenjivati u hrvatskim školama, pomoći u tom nastojanju.

Na važnost poučavanja učenika točnim činjenicama o homoseksualnoj orijentaciji upozorava i naš nalaz da su učenici koji više znaju o toj temi i koji su manje skloni diskriminirati homoseksualne osobe, ujedno i skloniji odabiru they were exposed to during their education in these two subjects.

Furthermore, it is possible that the resulting difference is due to differences in high school students' attitudes, which were not the focus of this study. Research has consistently shown differences in attitudes toward homosexuals with respect to religiosity (Whitley, 2009; Roggemans, Spruyt, Van Droogenbroeck, and Keppens, 2015), that is, people who attach more importance to religion in life tend to have more negative attitudes toward homosexuality. Since students most likely choose whether they want to attend religious instruction or ethics according to their initial attitudes and degree of religiosity, it is possible that the respondents differed in their knowledge of the topic even before high school.

Our third problem dealt with the relationship between knowledge about homosexual orientation and the tendency to discriminate against homosexuals. Although the students were generally not particularly inclined to discriminate against homosexuals, which is a positive result, a more detailed analysis showed that a significant number of the respondents would be ready to discriminate in certain situations. Thus, just over a fifth of the students would prohibit homosexual persons from making physical contact in public, which is in line with the findings of research by Bagić and Gvozdanović (2015), and Bovan and Širinić (2016). The highest percentage of discriminatory answers was given in the statement On a trip, I would rather share a room with a heterosexual than a homosexual person of my gender, that is, as many as a third of the respondents would prefer a heterosexual person over a homosexual one in this situation. The lowest percentages of discriminatory answers were given in the statements involving the respondents eliminating homosexual persons from their lives 
daljnjeg educiranja o tome, a čime smo potvrdili svoju hipotezu postavljenu u sklopu četvrtog problema. Čini se da slabije znanje, ne samo da učenike čini sklonijima diskriminirati homoseksualne osobe nego ih čini i zatvorenijima prema novim informacijama o tome, a što bi potencijalno moglo promijeniti njihova početna uvjerenja. Na taj način učenici potencijalno mogu ostati vrtjeti se u krugu slaboga znanja i posljedično diskriminatornih ponašanja prema homoseksualnim osobama. Dodatno, taj nalaz upozorava da, kada se radi o znanju o društvenim skupinama, jednostavna izloženost informacijama (primjerice ispunjavanje upitnika u kojem se ispituje znanje o temi) nije dovoljan motivator za daljnje učenje o temi, kao što se to pokazuje u nekim istraživanjima (Ditta i sur., 2020). Nastavnici i učitelji, koji odluče poučavati o homoseksualnosti u školi, trebaju biti svjesni da nije dovoljno učenicima nove informacije izložiti jednom ili površno, već da treba posvetiti više vremena i opetovano ih izlagati informacijama, ne bi li se postigao krajnji cilj.

\section{METODOLOŠKA OGRANIČENJA I BUDUĆA ISTRAŽIVANJA}

Važno je spomenuti da je ovo istraživanje imalo određena metodološka ograničenja. Za početak, podatke smo prikupljali online, te na prigodnom uzorku adolescenata, zbog čega trebamo biti oprezni u generalizaciji rezultata na cijelu populaciju srednjoškolaca u Hrvatskoj. Također, naši podatci dobiveni su na uzorku u kojem je bilo više sudionica nego sudionika, učenika gimnazija u odnosu na druge srednjoškolske programe te više osoba prosječnoga ili iznadprosječnog socioekonomskog statusa. Osim toga, uzorak je vjerojatno i pristran u smislu da su sudionici s pozitivnijim stavovima o toj temi bili i spremniji sudjelovati u istraživanju. Prezastupljenost tih skupina mogla je dovesti do pozitivnijih rezultata. Ipak, uzorak (e.g. If I found out that my favorite singer was homosexual, I would stop listening to him/her). Both of these findings are consistent with the research of Huić, Jelić and Kamenov (2016) conducted on the adult population, which hypothesized that the statement about who one would share a room with is an example of covert heterosexism, and therefore a method of self-expression, less susceptible to socially desirable answers. They also state that this example is likely to provoke more emotional reactions that may underlie stereotypes and prejudices towards homosexuals (disgust, anger, and fear) (Herek, 2004).

Although previous research has not been unequivocal in establishing a link between knowledge and tendency to discriminate (Cramwinckel, Scheepers, \& van der Toorn, 2018), this study confirmed our initial assumption. Students with poorer knowledge were more likely to discriminate against homosexuals. This finding is important because tendency to discriminate is a measure of behavioral intention, which in turn is the most important predictor of actual behavior (Ajzen, 1991). Additionally, this finding once again points at the danger of misconceptions about homosexual orientation. The school, as an educational institution, which should educate socially responsible citizens, not only has a responsibility to prevent violence and discrimination based on homosexual orientation, but also to teach young people accurate facts about homosexual orientation. As our findings indicate, the knowledge gained has the potential to contribute to reducing discrimination against homosexuals. This would mean that this topic, as well as topics related to sexuality in general, should not be avoided in schools. Hopefully, the curricula of the cross-curricular topics Personal and Social Development, Health and Civic Education, which have started to be applied in Croatian schools 
je dosta heterogen, a i sastoji se isključivo od srednjoškolske populacije na kojoj se takva istraživanja rijetko provode. Također, baš zbog toga što očekujemo da su rezultati pozitivniji od cijele populacije, oni su dodatno zabrinjavajući jer pokazuju tendenciju prema diskriminaciji i prilično slabo znanje adolescenata. Buduća istraživanja trebala bi pokušati zahvatiti reprezentativni uzorak srednjoškolaca prije donošenja konačnih zaključaka o temi. Osim toga, mali postotak srednjoškolaca u uzorku bio je homoseksualne orijentacije. lako je taj postotak premalen da bi mogao značajno utjecati na rezultate, budućim istraživanjima bilo bi zanimljivo zahvatiti širu populaciju homoseksualnih učenika, te ispitati razlike u znanju između njih i heteroseksualnih učenika. Također, buduća istraživanja čimbenika povezanih sa znanjem o homoseksualnoj orijentaciji trebala bi provjeriti potencijalnu ulogu akademske uspješnosti i motivacije u tom znanju. Naime, istraživanja pokazuju da uspješniji učenici imaju i više razine potrebe za spoznajom (Luong i sur., 2017), te je moguće da su individualne razlike poput tih, zapravo povezane s time jesu li učenici odlučili pročitati dodatni edukacijski materijal o homoseksualnosti.

Nadalje, online prikupljanje podataka karakterizirano je nepostojanjem kontrole nad procesom ispunjavanja upitnika, te pristranije uzorkovanje s obzirom na socioekonomski status. Odabrali smo takvu metodu iz nekoliko razloga, između ostaloga da bismo došli do što većeg i različitijeg uzorka. S obzirom da je tema još uvijek kontroverzna, smatrali smo da će online ispunjavanje sudionicima pružiti privatnost koju im u grupnom, razrednom ispitivanju, ne bismo mogli omogućiti (Gosling i Mason, 2015).

Dodatno, zbog toga što smo ispitivali populaciju adolescenata od 14 godina naviše, morali smo uključiti i informacije za roditelje as part of the curricular reform, will help in this endeavor.

The importance of teaching students accurate facts about homosexual orientation is indicated by our finding that students who know more about this topic and are less likely to discriminate against homosexuals are also more likely to choose to further educate themselves on the topic, thus confirming our assumption from the fourth research problem. Poorer knowledge seems to not only make students more prone to discriminate against homosexuals, but also make them more closed to new information on the topic that could potentially change their initial beliefs. That way, students can potentially remain in a circle of poor knowledge and, consequently, discriminatory behaviors towards homosexuals. In addition, this finding indicates that, when it comes to knowledge about social groups, simple exposure to information (for example, completing a questionnaire examining knowledge on a topic) is not a sufficient motivator for further learning about a topic, as shown in some research (Ditta et al., 2020). Teachers who choose to teach about homosexuality in school should be aware that it is not enough to expose students to new information once or superficially, but to devote more time and repeatedly expose them to information in order to achieve the end goal.

\section{METHODOLOGICAL LIMITATIONS AND FUTURE RESEARCH}

It is noteworthy that this study has certain methodological limitations. For a start, we collected data online, and on a convenient sample of adolescents, which is why we need to be careful in generalizing the findings to the entire population of high school students in Croatia. Additionally, our data were obtained 
te tražiti potvrdu da su sudionici obavijestili roditelje i prenijeli im te informacije. lako nam na tom pitanju nije otpalo mnogo sudionika, na rezultate je mogla utjecati već sama činjenica da su prije rješavanja upitnika sudionici razgovarali o temi istraživanja s roditeljima. Svejedno, smatrali smo važnim ispitati baš srednjoškolsku populaciju zbog nedostataka istraživanja o tome na toj populaciji, pogotovo s obzirom na to da se nalaze u životnoj fazi kada razvijaju vlastiti identitet i stavove. Zbog toga smatramo da smo unatoč nedostatcima prikupili vrijedne podatke koji mogu otvoriti vrata budućim istraživanjima.

S obzirom na to da smo ispitivali isključivo povezanosti, korelacijskim istraživanjem nije moguće govoriti o uzročno-posljedičnoj vezi znanja i sklonosti diskriminaciji. Ipak, s obzirom na neka druga istraživanja (Porter i Krinsky, 2014), koja su pokazala da povećanje znanja može dovesti do smanjene homonegativnosti te činjenicu da smo dobili povezanost između znanja i sklonosti diskriminaciji, mislimo da smo postavili temelje za buduća istraživanja u tom području. Bilo bi zanimljivo provesti eksperimentalno istraživanje i ispitati bi li neka intervencija mogla utjecati na sklonost diskriminaciji, što je zapravo i najjača praktična implikacija ovog istraživanja. Ako određene odrednice obrazovnog sustava mogu poboljšati učeničko znanje, a time dovesti do smanjenja diskriminacije, to bi svakako trebao biti poticaj za razvoj dodatnog obrazovanja o toj temi, novog kurikula građanskog odgoja ili posebnih radionica i tečajeva. Također, s obzirom na to da smo ispitivali samo sklonost diskriminaciji, a ne i konkretno diskriminativno ponašanje, bilo bi zanimljivo ispitati i kakvo bi bilo stvarno ponašanje.

Osim toga, buduća istraživanja trebala bi dalje razvijati i validirati instrumente i mjere koje smo koristili u ovom istraživanju. Naime, on a sample including more female than male respondents, more grammar school students compared to other high school programs, and more persons of average or above-average socio-economic status. Besides, the sample is probably also biased in the sense that respondents with more affirmative attitudes about this topic were more willing to participate in the survey. Overrepresentation of these groups may have led to more positive results. However, the sample is quite heterogeneous, and consists exclusively of the high school population, where such research is rarely conducted. Also, just because we expect the findings to be more positive than those for the entire population, they are additionally concerning as they show a tendency towards discrimination and a rather poor knowledge of adolescents. Future research should attempt to capture a representative sample of high school students, before reaching final conclusions on the topic. In addition, a small percentage of the high school students in the sample were homosexual. Although this percentage is too slight to significantly influence the findings, it would be interesting to cover a wider population of homosexual students in future research, and examine differences in the knowledge between them and heterosexual students. Moreover, future research on factors related to knowledge about homosexual orientation should examine the potential role of academic performance and motivation in that knowledge, as research shows that more successful students tend to have higher levels of need for learning (Luong et al., 2017), and it is possible that individual differences like these are actually related to whether students choose to read additional educational material on homosexuality.

Furthermore, online data collection is characterized by a lack of control over the questionnaire completion process, and more biased sampling with respect to socioeconomic 
skala kojom smo ispitali znanje nije imala podjednak broj točnih i netočnih odgovora, a što je moglo utjecati na naše rezultate. Također, mjera zastupljenosti obrazovnih sadržaja vezanih uz homoseksualnu orijentaciju temeljila se isključivo na subjektivnoj percepciji i dosjećanju učenika, što je također nedostatak istraživanja. Buduća istraživanja trebala bi uključiti neku objektivniju mjeru, npr. prikupiti podatke od nastavnika ili iz nastavnih priprema, odnosno školskog kurikula. Takva bi mjera bolje zahvatila konstrukt pa bi se možda hipoteza o povezanosti boljeg znanja s većim stupnjem izloženosti informacijama o homoseksualnoj orijentaciji i pokazala značajnom.

\section{ZAKLJUČAK}

Istraživanje je pokazalo da je znanje srednjoškolaca o homoseksualnoj orijentaciji relativno slabo, te da su srednjoškolci relativno sigurni; umjesto u znanstvene činjenice, u različite mitove o homoseksualnosti (npr. da se homoseksualne osobe lako prepozna prema izgledu i ponašanju). Srednjoškolci navode da su u školi tek neslužbeno ili površno slušali o tome, i to u prosjeku na jednom do dva školska predmeta. Hipoteza o povezanosti boljeg znanja o homoseksualnoj orijentaciji s većom percepcijom izloženosti temi, nije se potvrdila. Međutim, potvrdili smo hipotezu o boljem znanju onih učenika koji pohađaju etiku, od onih učenika koji pohađaju vjeronauk. Srednjoškolci s boljim znanjem o homoseksualnoj orijentaciji manje su skloni diskriminirati osobe homoseksualne orijentacije, a čini se da su i otvoreniji birati čitanje edukacijskog materijala o temi, čime smo potvrdili svoje hipoteze vezane uz treći i četvrti istraživački problem. lako su, prije donošenja konačnih zaključaka, potrebna buduća istraživanja tog fenomena na reprezentativnom uzorku i s objektivnijim status. We chose this method for several reasons, also to obtain as large and different a sample as possible. Given that the topic is still controversial, we felt that online completion would provide respondents with privacy that we would not be able to provide during a group survey in the classroom (Gosling and Mason, 2015).

Additionally, because we surveyed a population of adolescents 14 years of age and older, we had to include information for parents and seek confirmation that the respondents had informed parents and passed that information on to them. Although we did not lose many respondents because of this, the findings could be influenced by the very fact that the respondents had discussed the research topic with their parents before completing the questionnaire. Nevertheless, we considered it essential to examine the high school population given the lack of research about this topic on that population, especially considering that they are in a phase of life in which they develop their own identity and attitudes. We therefore believe that, despite the shortcomings, we have collected valuable data that can open the door to future research.

Since we only examined the connections, through correlational research, it is not possible to talk about the cause-and-effect relationship of knowledge and the tendency to discriminate. However, given some other research (Porter and Krinsky, 2014) that showed that increasing knowledge can lead to reduced homonegativity, and the fact that we established a link between knowledge and the tendency to discriminate, we believe that we have laid the groundwork for future research in this area. It would be interesting to conduct an experimental study and examine whether the tendency to discriminate could be affected by an intervention, which is indeed the strongest practical implication of 
mjerama, ovo istraživanje pruža važne podatke o populaciji koja je rijetko istraživana o tome u Hrvatskoj.

Tijekom srednje škole, adolescenti se nalaze u jednom od najosjetljivijih razdoblja svojeg života te prolaze mnoge biološke i psihičke promjene koje kod mnogih stvaraju nesigurnost, sram, zbunjenost i ostale osjećaje koje vežemo uz pubertet (Berk, 2005). Izrazito je važno da se svima njima pruži najbolje moguće iskustvo adolescencije i srednjoškolskog obrazovanja, a to znači iskustvo bez diskriminacije. Važno je da svim adolescentima damo alate koji su im potrebni da se snađu u takvim društvenim pitanjima i da ih educiramo kako da budu bolji građani i bolji kolege. lako je idealno s takvim obrazovanjem početi od najranije dobi, ključno je to učiniti najkasnije u srednjoj školi, što je i stupanj obrazovanja koji većina Hrvata završi. this research. If certain determinants of the education system can improve students' knowledge and thus lead to a reduction in discrimination, that should certainly be an incentive for developing additional training about this topic, a new curriculum for civic education, or special workshops and courses. Also, as we only examined the tendency to discriminate, and not specifically discriminatory behavior, it would be interesting to examine what the actual behavior would be.

In addition, future research should further develop and validate the instruments and measures we applied in this study. The scale used to examine the knowledge did not have an equal number of correct and incorrect answers, which may have affected our results. Also, the level of presence of educational content related to homosexual orientation was based solely on the students' subjective perception and recollection, which is another shortcoming of the study. Future research should include a more objective measure, such as collecting data from teachers or teaching preparations, or from school curricula. Such a measure would better capture the construct, and perhaps the assumption about a link between better knowledge and a greater degree of exposure to information about homosexual orientation would prove significant.

\section{CONCLUSION}

The study has shown that high school students' knowledge about homosexual orientation is relatively poor, and that high school students are relatively confident, instead of scientific facts, of various myths about homosexuality (e.g. that homosexuals are easily recognized by appearance and behavior). The students stated that they had only heard about the topic unofficially or superficially at school, 
on average in one to two school subjects. The assumption about a correlation between better knowledge about homosexual orientation and a higher perception of exposure to the topic has not been confirmed. However, we did confirm the assumption about better knowledge of those students who attend the subject of ethics than those who attend religious education. High school students with better knowledge about homosexual orientation are less likely to discriminate against homosexuals, and appear to be more open to choosing to read educational material on the topic, confirming our assumptions regarding the third and fourth research problems. Although future research on this phenomenon on a representative sample and with more objective measures is necessary before reaching final conclusions, this study provides important data on the population that has rarely been researched on this topic in Croatia.

During high school, adolescents find themselves in one of the most sensitive periods of their lives and undergo many biological and psychological changes that lead to insecurity, shame, confusion, and other feelings that many associate with puberty (Berk, 2005). It is essential to provide all of them with the best possible experience of adolescence and high school education, which means a non-discriminatory experience. It is important to give all adolescents the tools they need to cope with such social issues, and educate them on how to be better citizens and better colleagues. Although such education should ideally start from an early age, it is crucial to provide it at the latest in high school, which is the level of education that most Croatians complete. 


\section{LITERATURA/LITERATURE}

Ajzen, I. (1991). The Theory of Planned Behavior. Organizational Behavior and Human Decision Process, 50, 179-211

Alderson, K. G., Orzeck, T. L. i McEwen, S. C. (2009). Alberta High School Counsellors' Knowledge of Homosexuality and Their Attitudes Toward Gay Males. Canadian Journal of Education, 32(1), 87-11.

American Academy of Child \& Adolescent Psychiatry (2019). Facts for Families. Lesbain, Gay, Bisexual and Transgender Parents. Preuzeto s: https://www.aacap.org/AACAP/Families_and_Youth/ Facts_for_Families/FFF-Guide/Children-with-Lesbian-Gay-Bisexual-and-Transgender-Parents-092. aspx (10.03.2019.)

American Psychological Association (2008). Answers to your questions: For a better understanding of sexual orientation and homosexuality. Washington, DC. Preuzeto s: www.apa.org/topics/lgbt/ orientation.pdf (10.03.2019.)

Bagić, D. i Gvozdanović, A. (2015). Istraživanje političke pismenosti učenika završnih razreda srednjih škola u Hrvatskoj (izvješće). Zagreb: GONG i Institut za društvena istraživanja u Zagrebu.

Bartoş, S. E., Berger, I. i Hegarty, P. (2014). Interventions to reduce sexual prejudice: A study-space analysis and meta-analytic review. The Journal of Sex Research, 51(4), 363-382. https://doi.org/ 10.1080/00224499.2013.871625

Berk, L. (2005). Psihologija cjeloživotnog razvoja. Jastrebarsko: Naklada Slap.

Bovan, K. i Širinić, D. (2016). (Ne)demokratski stavovi maturanata u Hrvatskoj - prisutnost i odrednice. U M. Kovačić i M. Horvat (ur.), Od podanika do građana: Razvoj građanske kompetencije mladih (str. 73-90). Zagreb: Institut za društvena istraživanja u Zagrebu.

Brumen, S. (2012). LGBT Tematika u udžbenicima za srednju i osnovnu školu. Lezbijska udruga Kontra, Zagreb.

Cox, W. T. L., Devine, P. G., Bischmann, A. A. i Hyde, J. S. (2017) Ecological Invalidity of Existing Gaydar Research: In-Lab Accuracy Translates to Real-World Inaccuracy: Response to Rule, Johnson, \& Freeman (2016). The Journal of Sex Research, 54(7), 820-824. https://doi.org/10.1080/00224 499.2017.1278570

Cramwinckel, F. M., Scheepers, D. T. i van der Toorn, J. (2018) Interventions to Reduce Blatant and Subtle Sexual Orientation and Gender Identity Prejudice (SOGIP): Current Knowledge and Future Directions. Social Issues and Policy Review, 12(1), 183-217. https://doi.org/10.1111/sipr. 12044

Dankmeijer, P. (2017). GALE European Report 2017 on the Implementation of the Right to Education for Students who are Disadvantaged because of their Expression of Sexual Preference Or Gendered Identity. Amsterdam: GALE.

Deese, M. A. i Dawson, B. L. (2013). Changing attitudes toward LGBT students: An analysis of an awareness training paradigm aimed at increasing pro-LGBT attitudes. Papers \& Publications: Interdisciplinary Journal of Undergraduate Research, 2(1), 7.

Ditta, A. S., Strickland-Hughes, C. M., Cheung, C. i Wu, R. (2020). Exposure to information increases motivation to learn more. Learning and Motivation, 72, 101668. https://doi.org/10.1016/j. Imot.2020.101668

Epstein, R., McKinney, P., Fox, S. i Garcia, C. (2012). Support for a fluid-continuum model of sexual orientation: A large-scale Internet study. Journal of Homosexuality, 59(10), 1356-1381. https:// doi.org/10.1080/00918369.2012.724634 
Eurobarometar (2019). Eurobarometer 91. Brussells: European Commission.

Fiske, S. T. i Taylor, S. E. (2013). Social cognition: From brains to culture. Sage.

Fletcher, P. C., Anderson, J. M., Shanks, D. R., Honey, R., Carpenter, T. A., Donovan, T., Papadakis, N. i Bullmore, E. T. (2001). Responses of human frontal cortex to surprising events are predicted by formal associative learning theory. Nature Neuroscience, 4(10), 1043-1048. https://doi. org/10.1038/nn733

Gosling, S. D. i Mason, W. (2015). Internet Research in Psychology. The Annual Review of Psychology, 66, 26.1-26.6.

Gowen, L. K. i Winges-Yanez, N. (2014). Lesbian, Gay, Bisexual, Transgender, Queer, and Questioning Youths' Perspectives of Inclusive School-Based Sexuality Education. Journal of Sex Research, 51(7), 788-800. https://doi.org/10.1080/00224499.2013.806648

Haldeman, D. C. (2002). Gay rights, patient rights: The implications of sexual orientation conversion therapy. Professional Psychology: Research and Practice, 33(3), 260-264. https://doi. org/10.1037/0735-7028.33.3.260

Harackiewicz, J. M., Rozek, C. S., Hulleman, C. S. i Hyde, J. S. (2012). Helping parents to motivate adolescents in mathematics and science: An experimental test of a utility-value intervention. Psychological Science, 23(8), 899-906. https://doi.org/10.1177/0956797611435530

Haslam, N. i Levy, S. R. (2006). Essentialist beliefs about homosexuality: Structure and implications for prejudice. Personality and Social Psychology Bulletin, 32(4), 471-485. https://doi. org/10.1177/0146167205276516

Hegarty, P. (2010). A stone in the soup? Changes in sexual prejudice and essentialist beliefs among British students in a class on LGBT psychology. Psychology \& Sexuality, 1(1), 3-20. https://doi. org/10.1080/19419891003634356

Herek, G. M. (2000). The Psychology of Sexual Prejudice. Current Directions in Psychological Science, 9(1), 19-22. https://doi.org/10.1111/cdir.2000.9.issue-1

Herek, G. M. (2004). Beyond "homophobia": Thinking about sexual prejudice and stigma in the twenty-first century. Sexuality Research \& Social Policy, 1(2), 6-24. https://doi.org/10.1525/ srsp.2004.1.2.6

HIV and Gay and Bisexual Men Understanding HIV/AIDS (2018). Preuzeto s: $h$ ttps://aidsinfo.nih.gov/ understanding-hiv-aids/fact-sheets/25/81/hiv-and-gay-and-bisexual-men (01.03.2019.)

Hubbard, R. R., Snipes, D. J., Perrin, P. B., Morgan, M. R., DeJesus, A. i Bhattacharyya, S. (2013). Themes in heterosexuals' responses when challenging LGBT prejudice. Sexuality Research and Social Policy, 10(4), 269-278. https://doi.org/10.1007/s13178-013-0127-4

Huić, A., Jelić, M. i Kamenov, Ž. (2016). Što predviđa spremnost heteroseksualnih osoba na pozitivno i negativno ponašanje prema osobama homoseksualne orijentacije? Kriminologija $i$ socijalna integracija, 23(2), 79-109.

Huić, A., Jelić, M. i Kamenov, Ž. (2018). Essentialist Beliefs About Homosexuality Predict Positive and Negative Behavioral Intentions Toward Lesbian Women and Gay Men. Journal of Homosexuality, 65(12), 1631-1655. https://doi.org/10.1080/00918369.2017.1383104

Huić, A., Jugović, I. i Kamenov, Ž. (2015). Stavovi studenata o pravima osoba homoseksualne orijentacije. Revija za socijalnu politiku, 22(2), 219-244.

ILGA Europe (2020). Rainbow Europe 2020. Preuzeto s: https://www.ilga-europe.org/rainboweurope/2020 (01.11.2020.) 
Israel, T. i Mohr, J.J. (2004). Attitudes Towards Bisexual Women and Men. Journal of Bisexuality, 4, 117-134.

Kamenov, Ž., Jelić, M. i Huić, A. (2016). Problemi i izazovi seksualnih manjina u Hrvatskoj. Zagreb: FF Press.

Kelly, G. F. (2006). Sexuality Today: The Human Perspective. McGraw-Hill, New York.

Luong, C., Strobel, A., Wollschläger, R., Greiff, S., Vainikainen, M. P. i Preckel, F. (2017). Need for cognition in children and adolescents: Behavioral correlates and relations to academic achievement and potential. Learning and Individual Differences, 53, 103-113.

Ohlander, J., Batalova J. i Treas, J. (2005). Explaining educational influences on attitudes toward homosexual relations. Social Science Research, 34, 781-799.

Markus, H. i Zajonc, R. B. (1985). The cognitive perspective in social psychology. Handbook of social psychology, 1, 137-230.

Meyer, I. H. (2003). Prejudice, social stress, and mental health in lesbian, gay, and bisexual populations: conceptual issues and research evidence. Psychological Bulletin, 129(5), 674.

Pikić, A. i Jugović, I. (2006). Nasilje nad lezbijkama, gejevima i biseksualnim osobama u Hrvatskoj: izvještaj istraživanja. Zagreb: Lezbijska grupa Kontra.

Porter, K. E. i Krinsky, L. (2014). Do LGBT Aging Trainings Effectuate Positive Change in Mainstream Elder Service Providers? Journal of Homosexuality, 61, 197-216.

Roggemans, L., Spruyt, B., van Droogenbroeck, F. i Keppens, G. (2015). Religion and Negative Attitudes towards Homosexuals: An Analysis of Urban Young People and Their Attitudes towards Homosexuality. Young, 23(3), 254-276. https://doi.org/10.1177/1103308815586903

Savin-Williams, R. C. (2014). An exploratory study of the categorical versus spectrum nature of sexual orientation. The Journal of Sex Research, 51(4), 446-453. https://doi.org/10.1080/00224 499.2013.871691

Ured Pravobraniteljice za ravnopravnost spolova (2015). Izvješće o radu Pravobraniteljice za ravnopravnost spolova za 2014. godinu. Zagreb.

Waterman, A. D., Reid, J. D., Garfield, L. D. i Hoy, S. J. (2001). From curiosity to care: Heterosexual student interest in sexual diversity courses. Teaching of Psychology, 28(1), 21-26.

Wells, J. W. i Franken, M. L. (1987). University students' knowledge about and attitudes toward homosexuality. The Journal of Humanistic Education and Development, 26(2), 81-95.

Whitley Jr, B. E. (2009). Religiosity and attitudes toward lesbians and gay men: A meta-analysis. International Journal for the Psychology of Religion, 19(1), 21-38. 